Marquette University

e-Publications@Marquette

$8-2-2015$

Scope and Mechanistic Analysis for Chemoselective Hydrogenolysis of Carbonyl Compounds Catalyzed by a Cationic Ruthenium Hydride Complex with a Tunable Phenol Ligand

Nishantha Kumara Kalutharage

Marquette University

Chae S. Yi

Marquette University, chae.yi@marquette.edu

Accepted version. Journal of the American Chemical Society, Vol 137, No. 34 (August 2, 2015):

11105-11114. DOI. (C) 2015 American Chemical Society. Used with permission. 


\title{
Scope and Mechanistic Analysis for Chemoselective Hydrogenolysis of Carbonyl Compounds Catalyzed by a Cationic Ruthenium Hydride Complex with a Tunable Phenol Ligand
}

\author{
Nishantha Kalutharage \\ Department of Chemistry, Marquette University, \\ Milwaukee, WI \\ Chae S. Yi \\ Department of Chemistry, Marquette University, \\ Milwaukee, WI
}




\section{Abstract}

\section{Catalytic Hydrogenolysis of Aldehydes and Ketones with $\mathrm{H}_{2}$}<smiles></smiles>

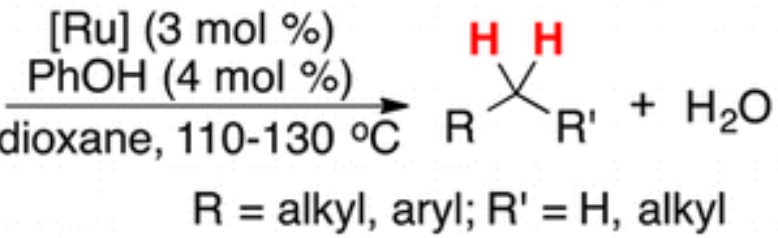

- Employs non-toxic and cheaply available $\mathrm{H}_{2}$

- Chemselective hydrogenolysis of biologically active substrates

- Formation of water as the sole byproduct

- Tunable catalytic activity using phenol ligands

A cationic ruthenium hydride complex, $\left[\left(\mathrm{C}_{6} \mathrm{H}_{6}\right)\left(\mathrm{PCy}_{3}\right)(\mathrm{CO}) \mathrm{RuH}^{+} \mathrm{BF}_{4}^{-}(\mathbf{1})\right.$, with a phenol ligand was found to exhibit high catalytic activity for the hydrogenolysis of carbonyl compounds to yield the corresponding aliphatic products. The catalytic method showed exceptionally high chemoselectivity toward the carbonyl reduction over alkene hydrogenation. Kinetic and spectroscopic studies revealed a strong electronic influence of the phenol ligand on the catalyst activity. The Hammett plot of the hydrogenolysis of 4methoxyacetophenone displayed two opposite linear slopes for the catalytic system $1 / p-\mathrm{X}-\mathrm{C}_{6} \mathrm{H}_{4} \mathrm{OH}$ ( $\rho=-3.3$ for $\mathrm{X}=\mathrm{OMe}, t-\mathrm{Bu}$, Et, and $\mathrm{Me} ; \rho=+1.5$ for $X=\mathrm{F}, \mathrm{Cl}$, and $\left.\mathrm{CF}_{3}\right)$. A normal deuterium isotope effect was observed for the hydrogenolysis reaction catalyzed by $1 / p-\mathrm{X}-\mathrm{C}_{6} \mathrm{H}_{4} \mathrm{OH}$ with an electron-releasing group $\left(k_{\mathrm{H}} / k_{\mathrm{D}}=1.7-2.5 ; \mathrm{X}=\mathrm{OMe}, \mathrm{Et}\right)$, whereas an inverse isotope effect was measured for $1 / p-\mathrm{X}-\mathrm{C}_{6} \mathrm{H}_{4} \mathrm{OH}$ with an electron-withdrawing group $\left(\mathrm{kH}_{\mathrm{H}} / \mathrm{k}_{\mathrm{D}}=\right.$ $0.6-0.7 ; \mathrm{X}=\mathrm{Cl}, \mathrm{CF}_{3}$ ). The empirical rate law was determined from the hydrogenolysis of 4-methoxyacetophenone: rate $=k_{\text {obsd }}[\mathrm{Ru}]\left[\right.$ ketone] $\left[\mathrm{H}_{2}\right]^{-1}$ for the reaction catalyzed by $\mathbf{1} / p-\mathrm{OMe}-\mathrm{C}_{6} \mathrm{H}_{4} \mathrm{OH}$, and rate $=k_{\text {obsd }}[\mathrm{Ru}][$ ketone $]\left[\mathrm{H}_{2}\right]^{0}$ for the reaction catalyzed by $1 / p-\mathrm{CF}_{3}-\mathrm{C}_{6} \mathrm{H}_{4} \mathrm{OH}$. Catalytically relevant dinuclear ruthenium hydride and hydroxo complexes were synthesized, and their structures were established by X-ray crystallography. Two distinct mechanistic pathways are presented for the hydrogenolysis reaction on the basis of these kinetic and spectroscopic data.

\section{Introduction}

Transition-metal-catalyzed $\mathrm{C}=\mathrm{O}$ cleavage reactions of oxygenated organic compounds continue to attract broad interests in catalysis research fields because of their fundamental importance in both industrial-scale petroleum and biomass feedstock reforming processes as well as in organic synthesis of biologically active molecules. ${ }^{1}$ In traditional organic synthesis, both Clemmensen and Wolff-Kishner methods have been widely used for the reduction of 
aldehydes and ketones to the corresponding aliphatic products. ${ }^{2}$ However, these classical methods pose significant environmental and economic problems, especially in large-scale industrial processes, because they use stoichiometric reducing agents such as $\mathrm{Zn} / \mathrm{Hg}$ amalgam and hydrazine/KOH. To overcome such shortcomings associated with the stoichiometric methods, considerable efforts have been devoted to developing catalytic reduction methods for carbonyl compounds. ${ }^{3}$ In a pioneering study, Milstein and co-workers pertinently demonstrated the catalytic activity of Ru-pincer complexes toward hydrogenation and hydrogenolysis of esters and related carbonyl compounds. ${ }^{4}$ The Guan and Leitner groups independently employed pincer-ligated Fe catalysts to achieve highly selective hydrogenation of esters to alcohols. ${ }^{5}$ Pincer-ligated iridium hydride catalysts have been found to be particularly effective for direct hydrogenation of carboxylic acid derivatives and glycols as well as hydrosilylation of glucose. ${ }^{3 a, 6}$ Ligand-modified heterogeneous Pd catalysts have been found to be effective for the hydrogenolysis of carbonyl substrates, but these catalysts require silane as the reducing agent. ${ }^{7}$ Heterogeneous Pd and Pt catalysts have been successfully utilized for hydrodeoxygenation of biomass-derived furans into alkanes using $\mathrm{H}_{2}{ }^{8}$ A number of Lewis acid catalysts have also been used for silane-mediated reductive deoxygenation of carboxylic acid derivatives. ${ }^{9}$ In the field of homogeneous catalysis directed to organic synthesis, one of the central challenges has been centered on the design of catalytic hydrogenolysis methods which exhibit high chemoselectivity toward the carbonyl reduction over olefin hydrogenation.

Hydrogenolysis (deoxygenation) of alcohols and ether compounds constitutes another highly versatile functional group transformation in organic synthesis. ${ }^{10} \mathrm{~A}$ number of direct and indirect deoxygenation methods for alcohols and ethers have been developed over the years, and these have been successfully utilized to synthesize complex organic molecules. ${ }^{11}$ Since these classical methods employ a stoichiometric amount of metal reductants, recent research efforts have been focused on the development of catalytic $\mathrm{C}-\mathrm{O}$ bond hydrogenolysis methods for ethers and related oxygenated organic compounds. In a seminal paper, Hartwig and co-workers reported a highly effective $\mathrm{Ni}$-catalyzed hydrogenolysis of aryl ethers to form 
arenes and alcohols. ${ }^{12}$ A number of soluble transition-metal catalysts have been successfully employed to promote $\mathrm{C}-\mathrm{O}$ cleavage reactions of lignin analogues. ${ }^{13}$ Transition-metal oxo complexes have been found to exhibit promising catalytic activity for the deoxygenation of bioderived alcohols and polyols. ${ }^{14}$ In heterogeneous catalysis, mesoporous zeolite-supported metal catalysts have been shown to be particularly effective for selective hydrogenolysis of biomass-derived polyols and ethers. ${ }^{15}$ Heterogeneous zeolite catalysts have also been used for the commercial-scale methanol-to-olefin process to produce liquid hydrocarbon commodities. ${ }^{16}$ From the viewpoint of achieving green and sustainable chemistry, efficient catalytic $\mathrm{C}-\mathrm{O}$ bond cleavage methods are critically important for the conversion of oxygen-rich biomass feedstock into a renewable source of fine chemicals and liquid hydrocarbon fuels. ${ }^{17}$

We recently discovered that a well-defined cationic ruthenium hydride catalyst, $\left[\left(\mathrm{C}_{6} \mathrm{H}_{6}\right)\left(\mathrm{PCy}_{3}\right)(\mathrm{CO}) \mathrm{RuH}^{+} \mathrm{BF}_{4}^{-}(\mathbf{1})\right.$, is a highly effective catalyst precursor for a number of dehydrative $\mathrm{C}-\mathrm{H}$ coupling reactions of alkenes and arenes with alcohols. ${ }^{18}$ We also found that complex $\mathbf{1}$ catalyzes selective dehydrative etherification of alcohols and ketones. ${ }^{19}$ Since the formation of water has served as the driving force for mediating selective $\mathrm{C}-\mathrm{O}$ bond cleavage of alcohol substrates in these coupling reactions, we have been exploring the synthetic utility of dehydrative coupling reactions of carbonyl compounds. In this paper, we delineate full details of the discovery, substrate scope, and mechanistic study of the catalytic hydrogenolysis of carbonyl compounds to the corresponding aliphatic products. The unique features of the hydrogenolysis method are that it employs cheaply available $\mathrm{H}_{2}$ as the reducing agent, and utilizes tunable ligand-modified ruthenium hydride catalysts to achieve high activity and chemoselectivity for the catalytic reduction of ketones to aliphatic products without forming any wasteful byproducts.

\section{Results and Discussion}

In an effort to extend the scope of dehydrative coupling methods, we initially explored the catalytic activity of $\mathbf{1}$ for the dehydrative coupling of ketones with alcohols (Scheme 1). Following the previously optimized set of conditions, ${ }^{19 b}$ the treatment of 
acetophenone $(1.0 \mathrm{mmol})$ with 2-propanol $(2.5 \mathrm{mmol})$ in the presence of catalyst $1(2 \mathrm{~mol} \%)$ in chlorobenzene $(3 \mathrm{~mL})$ at $110{ }^{\circ} \mathrm{C}$ resulted in the selective formation of the ether product $\mathrm{PhCH}(\mathrm{Me}) \mathrm{OCHMe}_{2}$ in $72 \%$ yield. In a dramatically altered reactivity pattern, the analogous coupling of 2-acetylphenol with 2-propanol under otherwise similar reaction conditions unexpectedly formed 2-ethylphenol product $\mathbf{2 a}$ instead of the anticipated ether product. The product $\mathbf{2 a}$ apparently resulted from the carbonyl reduction of 2-acetylphenol.

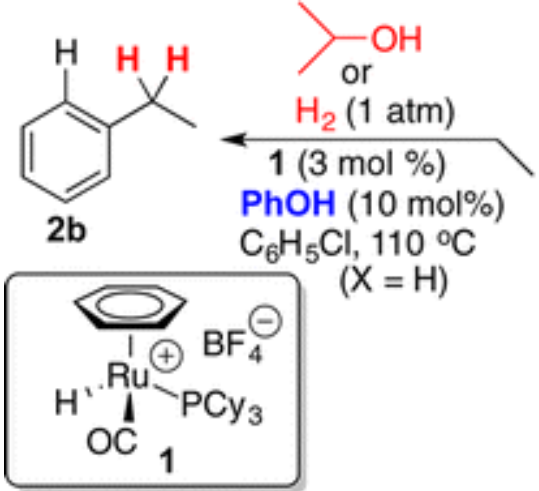

Scheme 1

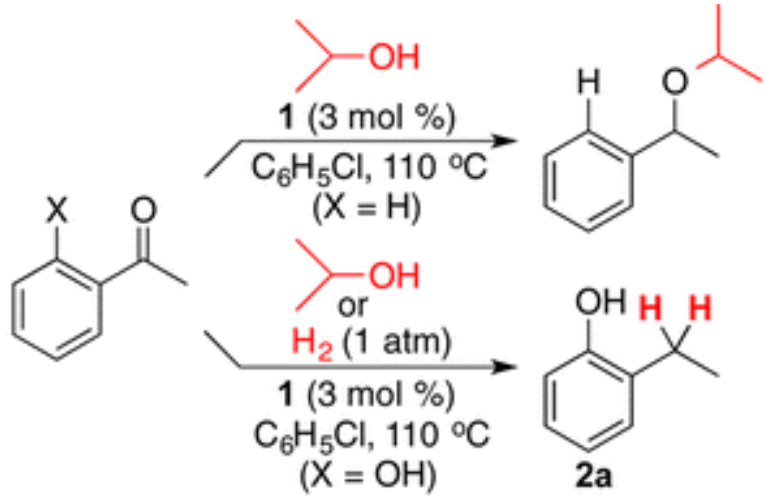

Suspecting that the phenol group might have assisted in the carbonyl reduction, we next examined the reaction of acetophenone with 2-propanol by using a catalytic amount of 1 ( $3 \mathrm{~mol} \%$ ) and phenol (10 mol \%). Indeed, the reaction selectively formed ethylbenzene $\mathbf{2} \mathbf{b}$ over the ether product. The analogous treatment of acetophenone with $\mathrm{H}_{2}(1 \mathrm{~atm})$ also gave the carbonyl reduction product $\mathbf{2 b}$ without forming the ether product. These initial results disclosed that phenol acted as the ligand for the Ru catalyst in steering its activity toward the carbonyl hydrogenolysis over the etherification reaction, where 2-propanol or $\mathrm{H}_{2}$ can be used as the reducing agent.

Encouraged by these initial results, we screened a number of oxygen and nitrogen donor ligands as well as ruthenium catalysts for the hydrogenolysis of 4-methoxyacetophenone with $\mathrm{H}_{2}$ (2 atm) (Table 1). The cationic Ru-H complex $\mathbf{1}$ with a phenol ligand exhibited the highest activity among screened oxygen and nitrogen donor ligands under the specified set of conditions (entries 1-8). Bidentate oxygen and nitrogen ligands showed a modest activity for the hydrogenolysis of 4-methoxyphenone (entries 3-8). The cationic Ru-H complex formed in situ from the reaction of the tetranuclear $\mathrm{Ru}-\mathrm{H}$ complex 
$\left\{\left[\left(\mathrm{PCy}_{3}\right)(\mathrm{CO}) \mathrm{RuH}\right]_{4}\left(\mu_{4}-\mathrm{O}\right)\left(\mu_{3}-\mathrm{OH}\right)\left(\mu_{2}-\mathrm{OH}\right)\right\}(3)$ with $\mathrm{HBF}_{4} \cdot \mathrm{OEt}_{2}$ and a phenol ligand also showed activity identical to that of $\mathbf{1} /$ phenol for the hydrogenolysis reaction (entry 10), ${ }^{20}$ and this procedure has been found to be particularly useful for measuring the kinetics (vide infra). Among screened solvents, both 1,4-dioxane and chlorobenzene were found to be most suitable for the hydrogenolysis reaction.

Table 1. Optimization Study for the Hydrogenolysis of 4Methoxyacetophenone ${ }^{a}$

\begin{tabular}{|c|c|c|c|c|}
\hline en & catalyst & ligand & solvent & yieldb (\%) \\
\hline 1 & 1 & phenol & dioxane & 95 \\
\hline 2 & 1 & phenol & $\mathrm{PhCl}$ & 89 \\
\hline 3 & 1 & aniline & $\mathrm{PhCl}$ & $<5$ \\
\hline 4 & 1 & 2- $\mathrm{NH}_{2} \mathrm{PhCOMe}$ & $\mathrm{PhCl}$ & 35 \\
\hline 5 & 1 & $\mathrm{PhCONH}_{2}$ & $\mathrm{PhCl}$ & $<5$ \\
\hline 6 & 1 & 1,2-catechol & toluene & 73 \\
\hline 7 & 1 & 1,1'-BINOL & toluene & 54 \\
\hline 8 & 1 & $1,2-\mathrm{C}_{6} \mathrm{H}_{4}\left(\mathrm{NH}_{2}\right)_{2}$ & toluene & $<5$ \\
\hline 9 & 3 & phenol & dioxane & $<5$ \\
\hline 10 & $\mathbf{3} / \mathrm{HBF}_{4} \cdot \mathrm{OEt}_{2}$ & phenol & dioxane & 95 \\
\hline 11 & {$\left[\mathrm{Ru}(\operatorname{cod}) \mathrm{Cl}_{2}\right]_{x}$} & phenol & dioxane & 0 \\
\hline 12 & $\mathrm{RuCl}_{3} \cdot 3 \mathrm{H}_{2} \mathrm{O}$ & phenol & dioxane & 0 \\
\hline 13 & $\mathrm{Ru}_{3}(\mathrm{CO})_{12}$ & phenol & dioxane & 0 \\
\hline 14 & $\left(\mathrm{PPh}_{3}\right)_{3}(\mathrm{CO}) \mathrm{RuH}_{2}$ & phenol & dioxane & 0 \\
\hline 15 & {$\left[\left(\mathrm{PCy}_{3}\right)_{2}(\mathrm{CO})\left(\mathrm{CH}_{3} \mathrm{CN}\right)_{2} \mathrm{RuH}_{1 \mathrm{~B} F_{4}}\right.$} & phenol & dioxane & 30 \\
\hline
\end{tabular}

aReaction conditions: 4-methoxyacetophenone $(1.0 \mathrm{mmol}), \mathrm{H}_{2}$ (2 atm), catalyst (3 $\mathrm{mol} \%)$, ligand $(10 \mathrm{~mol} \%)$, solvent $(2 \mathrm{~mL}), 130^{\circ} \mathrm{C}, 12 \mathrm{~h}$.

bThe product yield was determined by ${ }^{1} \mathrm{H}$ NMR by using methyl benzoate as an internal standard.

\section{Reaction Scope}

We surveyed the substrate scope of the hydrogenolysis reaction by using the catalytic system of $\mathbf{1} / \mathrm{PhOH}$ (Table 2 ). Both aliphatic and aryl-substituted aldehydes were effectively reduced to the corresponding alkyl products without forming any alcohols or other side products (entries 1-4). For the hydrogenolysis of an aliphatic enal substrate, a highly chemoselective hydrogenolysis of the aldehyde group was observed to form the product $\mathbf{2 f}$, without the $\mathrm{C}=\mathrm{C}$ bond hydrogenation (entry 4). The hydrogenolysis of both aliphatic and arylsubstituted ketones smoothly proceeded to afford the corresponding aliphatic products $\mathbf{2 g - 2 t}$ (entries 5-20). The hydrogenolysis of 
aliphatic ketones typically required a higher pressure of $\mathrm{H}_{2}$ than the aryl-substituted ketones, and in these cases, the hydrogenolysis using 2-propanol was found to be convenient in yielding the aliphatic products (entries 15 and 16). High chemoselectivity for the carbonyl hydrogenolysis for an enone substrate formed the corresponding olefin product $\mathbf{2 r}$ (entry 18). The hydrogenolysis of ketones containing oxygen and nitrogen atoms led to the corresponding aliphatic products 2q-2t (entries 17, 19, and 20).

Table 2. Catalytic Hydrogenolysis of Aldehydes and Ketones ${ }^{a}$

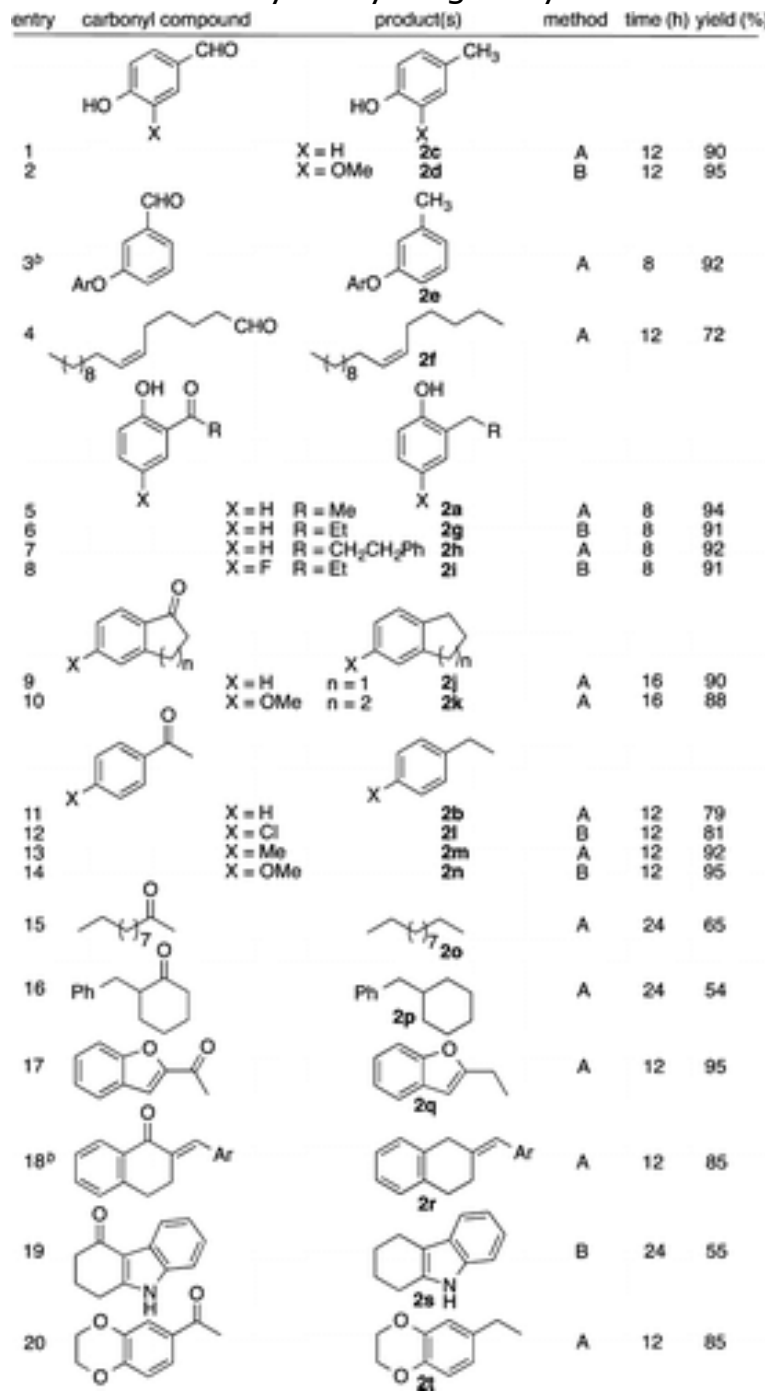

Table aMethod A: carbonyl compound (1.0 mmol), 2-propanol (2 mL), 1 (3 mol \%)/4methoxyphenol $(10 \mathrm{~mol} \%), 130^{\circ} \mathrm{C}$. Method B: carbonyl compound $(1.0 \mathrm{mmol}), \mathrm{H}_{2}(2$ atm), 1 (3 mol \%)/4-methoxyphenol (10 mol \%), $130{ }^{\circ} \mathrm{C}$, dioxane $(2 \mathrm{~mL})$. Table ${ }^{\mathrm{Ar}}=4$-methoxyphenyl. 
To further demonstrate its synthetic utility, we examined the hydrogenolysis of a number of highly functionalized, biologically active alcohol and carbonyl substrates (Table 3). For example, the treatment of cholesterol and progesterone led to the chemoselective hydrogenolysis of alcohol and ketone groups to form the corresponding aliphatic products $(-) \mathbf{- 2} \mathbf{u}$ and $(-) \mathbf{- 2 v}$, respectively, without giving any olefin hydrogenation products. In the case of progesterone, a 1:1 mixture of olefin isomerization products was obtained. For chloroamphenicol, chemoselective hydrogenolysis of benzylic alcohol was observed over the aliphatic alcohol in forming $(-) \mathbf{- 2 w}$, while the regioselective hydrogenolysis of the carbonyl anti to the catechol group for alizarin was achieved to give the product $\mathbf{2 x}$. The hydrogenolysis of haloperidol and ebastine cleanly yielded the corresponding aliphatic products $\mathbf{2 y}$ and $\mathbf{2 z}$, respectively, without forming any side products. The catalytic method exhibits high selectivity toward the hydrogenolysis of alcohol and ketone groups while tolerating common oxygen and nitrogen functional groups.

Table 3. Hydrogenolysis of Biologically Active Alcohols and Carbonyl Compounds ${ }^{a}$<smiles>CC(C)CCC[C@H](C)C1CCC2C3CC=C4CCCC[C@]4(C)C3CC[C@]21C</smiles>

$(-)-2 u 67 \%$<smiles>O=C(CCl)N[C@@H](CO)Cc1ccc([N+](=O)[O-])cc1</smiles>

$(-)-2 w 45 \%$<smiles>CCC1(C)CCN(CCCCc2ccc(F)cc2)CC1</smiles>

$(-)-2 y 68 \%$<smiles>CC(=O)[C@H]1CC[C@H]2[C@@H]3CC=C4CCCC[C@]4(C)[C@H]3CC[C@@]12C</smiles>

$(-)-2 v 52 \%(1: 1)$<smiles>O=C1c2ccccc2Cc2ccc(O)c(O)c21</smiles><smiles>[14CH3]</smiles><smiles>Cc1ccc(C)cc1</smiles>

Table aReaction conditions: alcohol/ketone (1.0 mmol), $\mathrm{H}_{2}$ (2 atm), 1 (3 mol \%)/4methoxyphenol $(10 \mathrm{~mol} \%)$, dioxane $(2 \mathrm{~mL}), 130^{\circ} \mathrm{C}, 12 \mathrm{~h}$. 


\section{Kinetics and Mechanistic Study: Hammett Study}

We performed the following kinetic studies to probe the detailed mechanism of the catalytic hydrogenolysis reaction. First, to gauge the electronic effect of the phenol ligand on the catalytic activity, we compared the rates of the hydrogenolysis reaction by using a series of para-substituted phenols, $p-\mathrm{X}-\mathrm{C}_{6} \mathrm{H}_{4} \mathrm{OH}(\mathrm{X}=\mathrm{OMe}, t-\mathrm{Bu}$, Et, $\mathrm{Me}, \mathrm{H}, \mathrm{F}$, $\mathrm{Cl}, \mathrm{CF}_{3}$ ) (eq 1 ). As noted before, the Ru catalyst generated in situ from $3 / \mathrm{HBF}_{4} \cdot \mathrm{OEt}_{2} / \mathrm{PhOH}$ was used in these kinetic experiments because it gives cleaner kinetics without any induction period compared to the isolated $\mathrm{Ru}-\mathrm{H}$ catalyst $\mathbf{1} / \mathrm{PhOH}$.

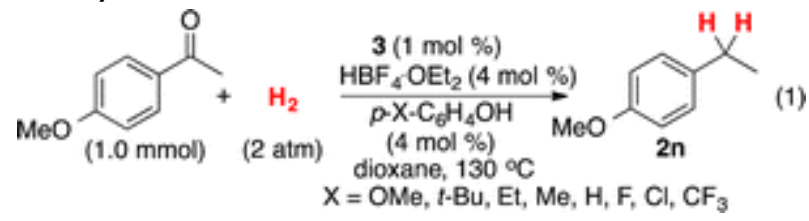

The rate of the hydrogenolysis of 4-methoxyacetophenone with $\mathrm{H}_{2}$ (2 atm) in the presence of 3 (1 mol \%)/HBF $4 \mathrm{OEt}_{2}(4 \mathrm{~mol} \%) / p-\mathrm{X}-$ $\mathrm{C}_{6} \mathrm{H}_{4} \mathrm{OH}(4 \mathrm{~mol} \%$ ) in dioxane was monitored by NMR. The appearance of the product peak was normalized against an internal standard (methyl benzoate) in 30 min intervals, and the $k_{\text {obsd }}$ of each catalytic reaction was determined from a first-order plot of $-\ln [(4-$ methoxyacetophenone $\left.)_{t} /(4-\text { methoxyacetophenone })_{0}\right]$ vs time. The Hammett plot of $\log \left(k_{\mathrm{x}} / k_{\mathrm{H}}\right)$ vs $\sigma_{\mathrm{p}}$ showed two opposite linear correlation patterns (Figure 1 ). Thus, a highly negative linear slope was observed for the phenols with an electron-donating group ( $\rho=$ $-3.3 \pm 0.3 ; \mathrm{X}=\mathrm{OMe}, t-\mathrm{Bu}, \mathrm{Et}, \mathrm{Me}, \mathrm{H})$, while a positive slope resulted from the phenols with an electron-withdrawing group $(\rho=+1.5 \pm 0.1$; $\left.\mathrm{X}=\mathrm{F}, \mathrm{Cl}, \mathrm{CF}_{3}\right)$, with an overall $\mathrm{V}$-shaped Hammett correlation. ${ }^{21}$ 


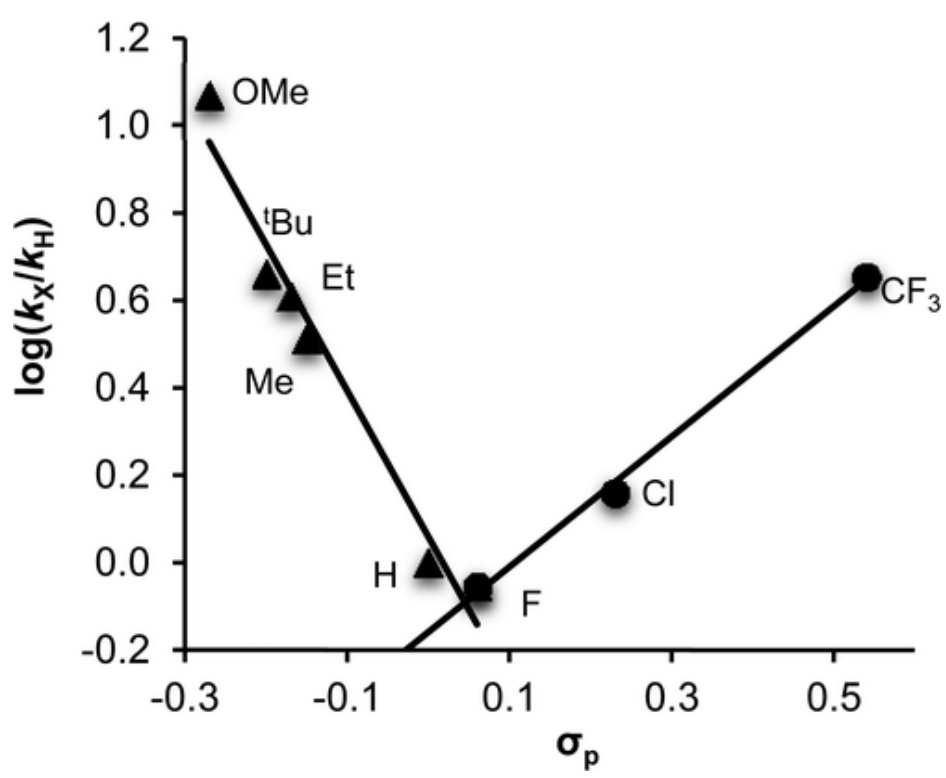

Figure 1. Hammett plot of the hydrogenolysis of 4-methoxyacetophenone catalyzed by $\mathbf{3} / \mathrm{HBF}_{4} \cdot \mathrm{OEt}_{2} / p-\mathrm{X}-\mathrm{C}_{6} \mathrm{H}_{4} \mathrm{OH}\left(\mathrm{X}=\mathrm{OMe}, t-\mathrm{Bu}, \mathrm{Et}, \mathrm{Me}, \mathrm{H}, \mathrm{F}, \mathrm{Cl}, \mathrm{CF}_{3}\right.$ ).

The V-shaped Hammett correlation has been generally attributed to a change in the reaction mechanism. ${ }^{22}$ In a recent example, Abu-Omar and co-workers reported a V-shaped Hammett plot in the hydrogen atom transfer reaction of Mn-imido complexes with the para-substituted phenols, from which the authors inferred two distinct hydrogen transfer mechanisms. ${ }^{22 b}$ While studying the oxygen atom transfer reaction of $\mathrm{Mn}$-oxo complexes, Goldberg and co-workers also observed a similar V-shaped Hammett correlation pattern for the reaction with para-substituted benzothioethers. ${ }^{22 c}$ In our case, the observation of a V-shaped Hammett correlation suggests that the activity of the ruthenium catalyst is dictated by two opposing electronic effects from the phenol ligand. For the reaction catalyzed by the Ru catalyst with an electron-releasing phenol ligand, a relatively electron-rich $\mathrm{Ru}$ center would facilitate the hydrogenolysis reaction by promoting the coordination and the activation of $\mathrm{H}_{2}$. On the other hand, the positive Hammett slope from the correlation of phenols with an electron-deficient group indicates that a relatively electrophilic $\mathrm{Ru}$ catalyst promotes the hydrogenolysis reaction through binding and activation of ketone and alcohol substrates. 
NOT THE PUBLISHED VERSION; this is the author's final, peer-reviewed manuscript. The published version may be accessed by following the link in the citation at the bottom of the page.

\section{Isotope Effect Study}

To probe the electronic effects on the $\mathrm{H}_{2}$ activation step, we measured the deuterium isotope effect for the hydrogenolysis reaction by using the Ru-H catalyst with a series of para-substituted phenol ligands (Scheme 2). The rate of hydrogenolysis of 4methoxyacetophenone with $\mathrm{H}_{2}(2 \mathrm{~atm})$ and with $\mathrm{D}_{2}(2 \mathrm{~atm})$ in the presence of in situ formed $3(1 \mathrm{~mol} \%) / \mathrm{HBF}_{4} \cdot \mathrm{OEt}_{2}(4 \mathrm{~mol} \%) / p$-OMe$\mathrm{C}_{6} \mathrm{H}_{4} \mathrm{OH}(4 \mathrm{~mol} \%)$ in dioxane at $130{ }^{\circ} \mathrm{C}$ was measured separately by monitoring the appearance of the product signals in ${ }^{1} \mathrm{H}$ NMR. The $k_{\text {obsd }}$ was determined from a first-order plot of $-\ln [(4-$ methoxyacetophenone) $t$ /(4-methoxyacetophenone $)_{0}$ ] vs time, and $k_{H} / k_{D}$ was calculated from the ratio of the slopes (Figure 2 ). The experiment was repeated by using other para-substituted phenol ligands, $p-\mathrm{X}-\mathrm{C}_{6} \mathrm{H}_{4} \mathrm{OH}\left(\mathrm{X}=\mathrm{OMe}, \mathrm{Et}, \mathrm{F}, \mathrm{Cl}, \mathrm{CF}_{3}\right)$, to obtain $k_{\mathrm{H}} / k_{\mathrm{D}}$ for each case (Figure $\mathrm{S} 2$ ).

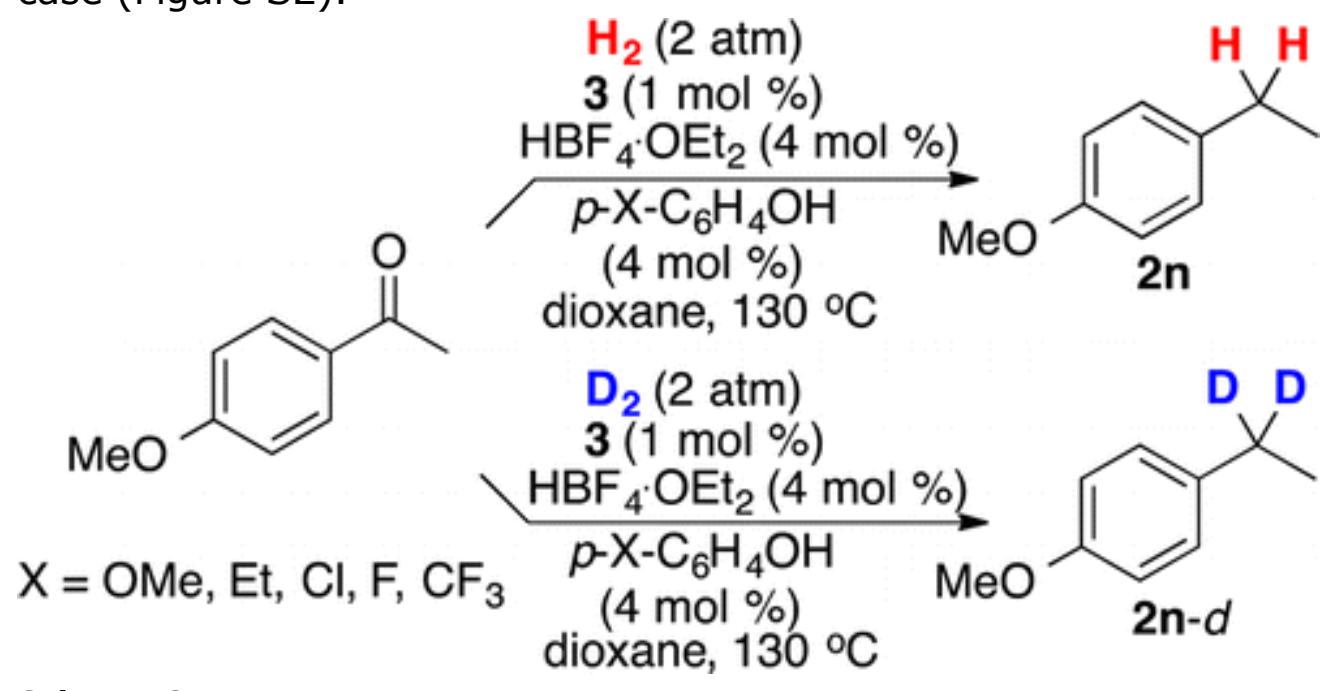

Scheme 2 


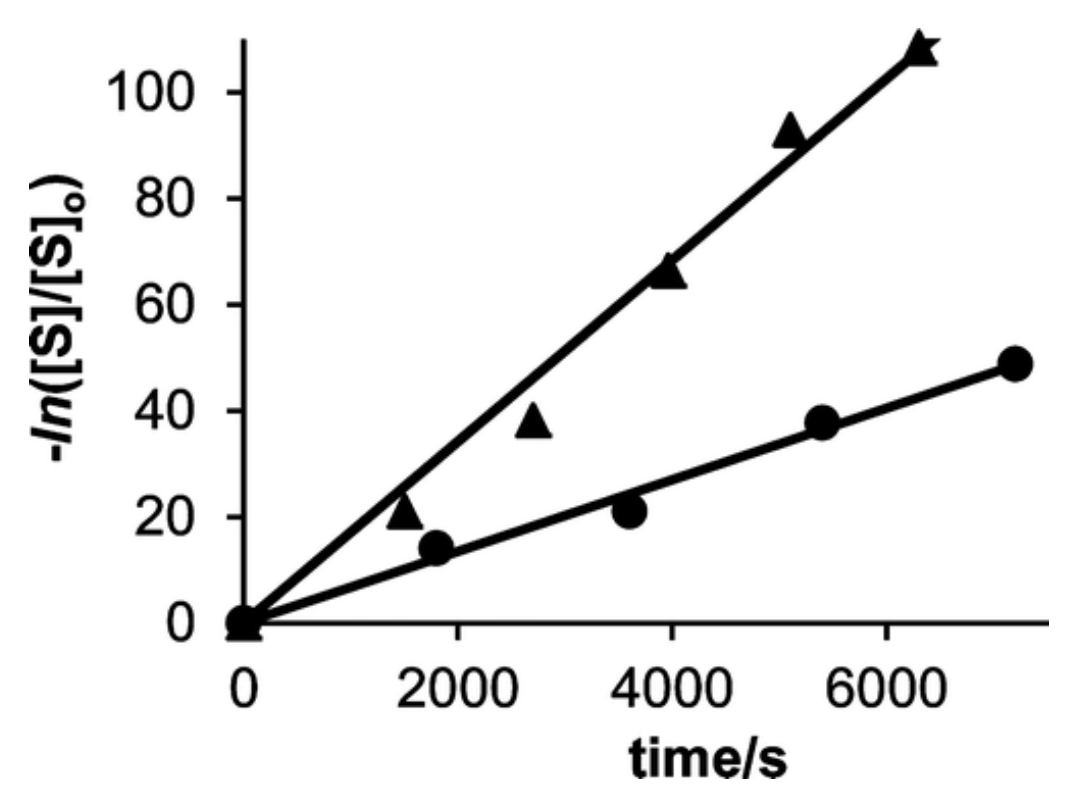

Figure 2. First-order plot for the hydrogenolysis of 4-methoxyacetophenone with $\mathrm{H}_{2}$ $(\boldsymbol{\Delta})$ and with $\mathrm{D}_{2}(\bullet)$ catalyzed by $\mathbf{3} / \mathrm{HBF}_{4} \cdot \mathrm{OEt}_{2} / p-\mathrm{OMe}-\mathrm{C}_{6} \mathrm{H}_{4} \mathrm{OH}$.

Table 4 lists the observed $k_{H} / k_{D}$ values for the hydrogenolysis reaction catalyzed by $3 / \mathrm{HBF}_{4} \cdot \mathrm{OEt}_{2} / p-\mathrm{X}-\mathrm{C}_{6} \mathrm{H}_{4} \mathrm{OH}$. A normal deuterium isotope effect was observed for the reaction catalyzed by phenols with an electron-releasing group ( $\mathrm{X}=\mathrm{OMe}, \mathrm{Et})$, while an inverse isotope effect was measured for phenols with an electron-withdrawing group $\left(\mathrm{X}=\mathrm{Cl}, \mathrm{CF}_{3}\right)$. A linear correlation of the isotope effect and electronic effect of the phenol ligand was established from the plot of $\log \left(k_{\mathrm{H}} / k_{\mathrm{D}}\right)$ vs $\sigma_{\mathrm{p}}$ (Figure S3). Since a relatively electron-rich Ru center should promote the coordination and activation of $\mathrm{H}_{2}$, the observed normal isotope effect signifies that the $\mathrm{H}-\mathrm{H}$ bond activation step is irreversible and that this elementary step is likely associated with the turnoverlimiting step for the Ru catalyst with an electron-releasing phenol ligand.

Table 4. Observed Deuterium Isotope Effect for the Hydrogenolysis of 4Methoxyacetophenone Catalyzed by $3 / \mathrm{HBF}_{4} \cdot \mathrm{OEt}_{2} / p-\mathrm{X}^{-} \mathrm{C}_{6} \mathrm{H}_{4} \mathrm{OH}^{\mathrm{a}}$

\begin{tabular}{llllll}
\multicolumn{1}{r}{$\mathbf{X}$} & \multicolumn{1}{c}{$\boldsymbol{k}_{\mathbf{H}} / \boldsymbol{k}_{\mathbf{D}}$} & \multicolumn{1}{c}{$\boldsymbol{\sigma}_{\mathbf{p}}$} & \multicolumn{1}{c}{$\mathbf{X}$} & $\boldsymbol{k}_{\mathbf{H}} / \boldsymbol{k}_{\mathbf{D}}$ & $\boldsymbol{\sigma}_{\mathbf{p}}$ \\
$\mathrm{OMe}$ & $2.7 \pm 0.3$ & -0.28 & $\mathrm{Cl}$ & $0.7 \pm 0.1$ & +0.24 \\
$\mathrm{Et}$ & $1.7 \pm 0.3$ & -0.14 & $\mathrm{CF}_{3}$ & $0.6 \pm 0.1$ & +0.53 \\
$\mathrm{~F}$ & $1.1 \pm 0.1$ & +0.15 & & &
\end{tabular}

aReaction conditions: carbonyl compound $(1.0 \mathrm{mmol}), \mathrm{H}_{2}$ (2 atm), 3 (1

$\mathrm{mol} \%) / \mathrm{HBF}_{4} \cdot \mathrm{OEt}_{2}(4 \mathrm{~mol} \%) / p-\mathrm{X}-\mathrm{C}_{6} \mathrm{H}_{4} \mathrm{OH}(10 \mathrm{~mol} \%), 130{ }^{\circ} \mathrm{C}$, dioxane $(2 \mathrm{~mL})$. 
In contrast, for the reaction catalyzed by the Ru catalyst with an electron-withdrawing phenol ligand, a relatively electron-poor $\mathrm{Ru}$ center is expected to have a relatively low $\mathrm{H}_{2}$ binding affinity. In this case, the observed inverse isotope effect is consistent with a stepwise reversible coordination of $\mathrm{H}_{2}$ followed by the partitioning of $\mathrm{H}_{2}$ resulting from an electron-poor Ru catalyst. A linear correlation of the magnitude of $k_{H} / k_{D}$ with the Hammett $\sigma_{\mathrm{p}}$ values indicates that the $\mathrm{H}_{2}$ activation step is strongly influenced by the electronic nature of the Ru catalyst. Electronic effects on the coordination and activation of $\mathrm{H}_{2}$ and related nonpolar substrates to organometallic complexes have been extensively investigated. ${ }^{23}$

An inverse deuterium isotope effect has been frequently observed for the transition-metal-mediated $\mathrm{C}-\mathrm{H}$ and $\mathrm{H}-\mathrm{H}$ bond activation reactions. ${ }^{24}$ For instance, the observed inverse isotope effect $\left(k_{\mathrm{H}} / k_{\mathrm{D}}=0.4-0.8\right)$ in reductive elimination of metal alkyl hydride complexes has been explained by invoking a stepwise reversible partitioning between alkyl hydride and $\sigma$-bonded metal complexes followed by a slow reductive elimination step of alkanes. ${ }^{24 b}$ The observation of inverse isotope effects in metal-mediated hydrogenation reactions has also been explained in terms of stepwise addition and activation of $\mathrm{H}_{2}$ to metal complexes. ${ }^{25}$

To discern the slow step of the catalytic reaction, we measured the ${ }^{12} \mathrm{C} /{ }^{13} \mathrm{C}$ isotope effect for the hydrogenolysis of 6-methoxy-1tetralone by employing Singleton's NMR technique (Scheme 3). ${ }^{26}$ To compare the electronic influence of the phenol ligand, we have chosen two electronically different phenol ligands, $p-\mathrm{X}-\mathrm{C}_{6} \mathrm{H}_{4} \mathrm{OH}(\mathrm{X}=\mathrm{OMe}$, $\left.\mathrm{CF}_{3}\right)$. The hydrogenolysis of 6-methoxy-1-tetralone $(10 \mathrm{mmol})$ was performed with $\mathrm{H}_{2}(2 \mathrm{~atm})$ and 3 (1 mol \%)/HBF 4 .OEt 2 (4 mol \%)/p-X$\mathrm{C}_{6} \mathrm{H}_{4} \mathrm{OH}\left(\mathrm{X}=\mathrm{OMe}\right.$ or $\left.\mathrm{CF}_{3}\right)(4 \mathrm{~mol} \%)$ in 1,4 -dioxane $(8 \mathrm{~mL})$ at $130{ }^{\circ} \mathrm{C}$ for 2-3 h. The product 6-methoxytetrahydronaphthalene ( $\mathbf{2 k}$ ) was isolated by column chromatography on silica gel (hexanes: $\mathrm{Et}_{2} \mathrm{O}=$ 40:1). The most pronounced carbon isotope effect on the a-carbon of the product $\mathbf{2} \mathbf{k}$ was observed when the average $\left[{ }^{13} \mathrm{C}\right]$ of the product at three low conversions (15\%, 18\%, and $20 \%$ ) was compared with that of the sample obtained at high conversion $(95 \%)$ for both cases $\left[\left(\left[{ }^{13} \mathrm{C}\right]\right.\right.$ at $95 \%$ conversion)/(average of $\left[{ }^{13} \mathrm{C}\right]$ at $17 \%$ conversion) at $\mathrm{C}(4)=$ 1.0424 for $\mathrm{X}=\mathrm{OMe}$ and 1.0627 for $\mathrm{X}=\mathrm{CF}_{3}$ ] (Tables S2 and S3). 


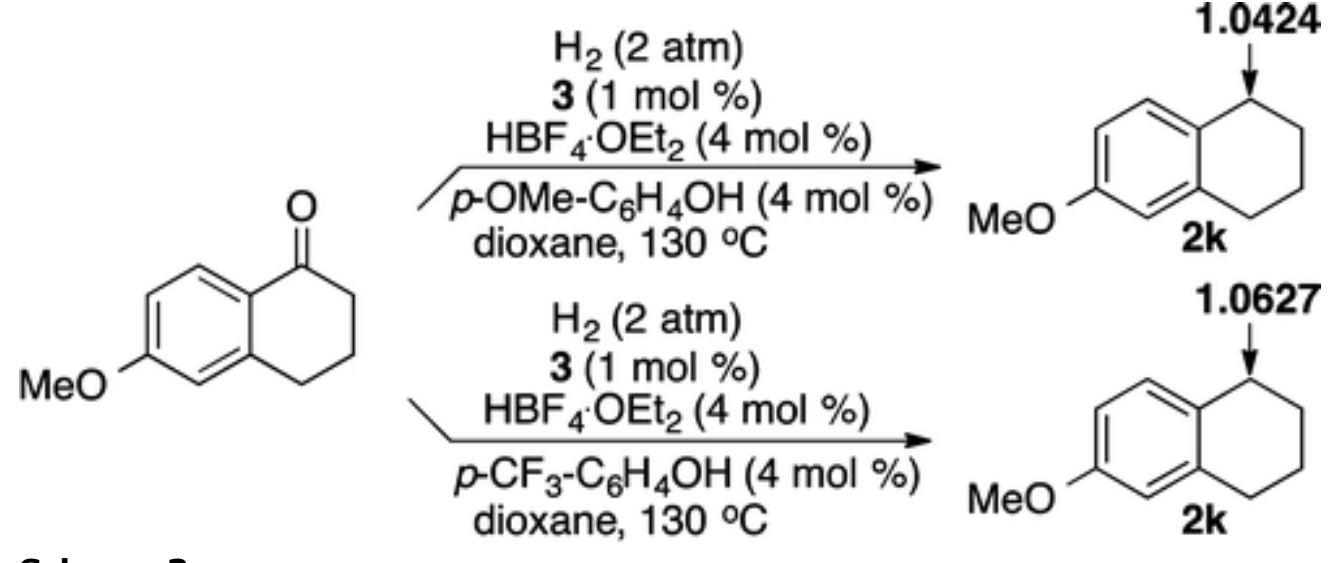

Scheme 3

The carbon isotope effect data indicated that the $\mathrm{C}-\mathrm{O}$ bond cleavage is the turnover-limiting step of the hydrogenolysis reaction for the Ru catalyst with both electron-releasing and -withdrawing phenol ligands. ${ }^{27}$ In support of this notion, Singleton and co-workers showed that the observation of a most pronounced carbon isotope effect has been a definitive tool for establishing the rate-limiting step for both $\mathrm{C}-\mathrm{C}$ and $\mathrm{C}-\mathrm{O}$ bond-forming reactions. ${ }^{28}$ The $\mathrm{C}-\mathrm{O}$ bond cleavage step has also been commonly considered as the turnoverlimiting step for catalytic reductive coupling reactions of ethers and related oxygenated compounds. ${ }^{29}$

\section{Deuterium Labeling Study}

To examine the H/D exchange pattern on the aliphatic products, 4-methoxyacetophenone $(1.0 \mathrm{mmol})$ was reacted with $\mathrm{D}_{2}(2 \mathrm{~atm})$ in the presence of $3 / \mathrm{HBF}_{4} \cdot \mathrm{OEt}_{2} / p-\mathrm{OMe}-\mathrm{C}_{6} \mathrm{H}_{4} \mathrm{OH}$ in dioxane at $130{ }^{\circ} \mathrm{C}$ (Scheme 4 ). The reaction was stopped after $4 \mathrm{~h}$ at $50 \%$ conversion, and the deuterium content of the isolated product $\mathbf{2 n}$ was analyzed by ${ }^{1} \mathrm{H}$ and ${ }^{2} \mathrm{H}$ NMR (Figure S4). The analogous treatment of 1-(4methoxyphenyl)ethanol $(1.0 \mathrm{mmol})$ with $\mathrm{D}_{2}(2 \mathrm{~atm})$ and $\mathbf{3} / \mathrm{HBF}_{4} \cdot \mathrm{OEt}_{2} / p-\mathrm{OMe}-\mathrm{C}_{6} \mathrm{H}_{4} \mathrm{OH}$ led to the same product $\mathbf{2 n}(50 \%$ conversion after $4 \mathrm{~h}$ ), and its deuterium content was compared with that of the product obtained from the ketone. 


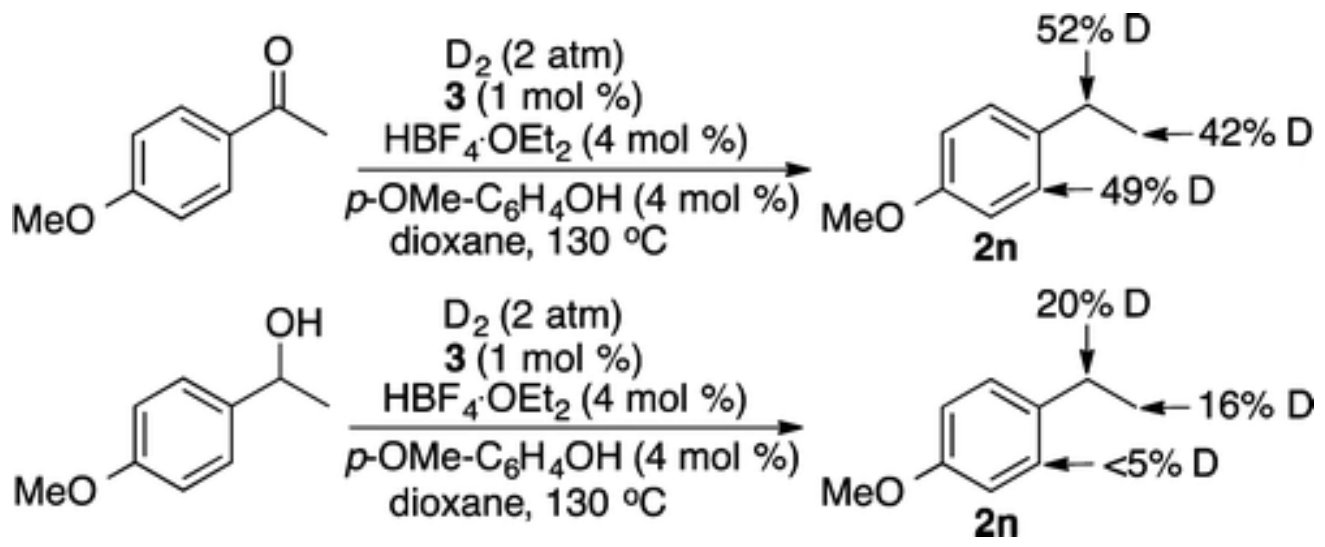

Scheme 4

As illustrated in Scheme 4, substantially higher deuterium incorporation was observed in the product $\mathbf{2 n}$ obtained from the hydrogenolysis of the ketone compared to the product obtained from the alcohol. For the hydrogenolysis of 4 -methoxyacetophenone, $42 \%$ deuterium in the $\beta-\mathrm{CH}_{3}$ group of the isolated product $\mathbf{2 n}$ suggests a facile H/D exchange via a keto-enol tautomerization of the ketone substrate, while $49 \%$ deuterium in the $o$-arene position can be explained via the chelate-assisted ortho-metalation and the reversible $\mathrm{H} / \mathrm{D}$ exchange. In chelate-assisted $\mathrm{C}-\mathrm{H}$ insertion reactions, reversible $\mathrm{O}$-arene $\mathrm{C}-\mathrm{H} / \mathrm{C}-\mathrm{D}$ exchange patterns have been commonly observed. ${ }^{30}$ In contrast, less than $5 \%$ deuterium in the 0 -arene position of the product was observed for the alcohol substrate, because in this case, the alcohol group could not serve as an effective chelate-directing group to promote 0 -arene H/D exchange. Similarly, $52 \%$ deuterium in the benzylic position of the product obtained from the ketone supports the notion for a rapid and reversible H/D exchange via keto-enol tautomerization and the subsequent hydrogenolysis processes. In contrast, a relatively small deuterium incorporation on the 0 -arene carbon of the product ( $\angle 5 \% \mathrm{D}$ ) obtained from the hydrogenolysis of 1 (4-methoxyphenyl)ethanol suggests that the hydrogenolysis occurs directly without the alcohol-to-ketone hydrogenation-dehydrogenation process. Also, lower than expected deuterium incorporation on the acarbon ( $20 \% \mathrm{D}$ in $\mathrm{CH}_{2}$ ) can be readily explained by an extensive $\mathrm{H} / \mathrm{D}$ exchange between $\mathrm{D}_{2}$ and $-\mathrm{OH}$ of alcohol substrates, which would dilute the deuterium content on $\mathrm{D}_{2}$. Transition-metal hydride complexes have been well-known to promote H/D exchange reactions between hydrocarbons and $\mathrm{H}_{2}$ with deuterated alcohols and water. ${ }^{31} \mathrm{~A}$ similar set of H/D exchange patterns was obtained for the Ru catalyst 
NOT THE PUBLISHED VERSION; this is the author's final, peer-reviewed manuscript. The published version may be accessed by following the link in the citation at the bottom of the page.

having an electron-withdrawing phenol ligand, $3 / \mathrm{HBF}_{4} \cdot \mathrm{OEt}_{2} / p-\mathrm{CF}_{3}-$ $\mathrm{C}_{6} \mathrm{H}_{4} \mathrm{OH}$ (Figure S5).

\section{Determination of the Empirical Rate Law}

To further discern the electronic effects of phenol ligands, we next determined the empirical rate law for the hydrogenolysis reaction of 4-methoxyacetophenone by using the Ru catalyst with both electron-releasing and -withdrawing phenol ligands. In a typical experimental setting, the active catalyst was generated in situ by combining 3 ( 1 mol \%)/ $\mathrm{HBF}_{4} \cdot \mathrm{OEt}_{2}(4 \mathrm{~mol} \%) / p-\mathrm{X}-\mathrm{C}_{6} \mathrm{H}_{4} \mathrm{OH}(4 \mathrm{~mol} \%)$ $\left(\mathrm{X}=\mathrm{OMe}, \mathrm{CF}_{3}\right)$. The initial rate was measured from the appearance of the product at five different catalyst concentrations (0.01-0.05 mM). The plot of the initial rate $\left(\mathrm{v}_{0}\right)$ as a function of [3] yielded a linear slope of $4.5 \times 10^{-6} \mathrm{~s}^{-1}$ for $3 / \mathrm{HBF}_{4} \cdot \mathrm{OEt}_{2} / p-\mathrm{OMe}-\mathrm{C}_{6} \mathrm{H}_{4} \mathrm{OH}$. The same set of experiments for the catalyst with an electron-withdrawing phenol ligand, $3 / \mathrm{HBF}_{4} \cdot \mathrm{OEt}_{2} / p-\mathrm{CF}_{3}-\mathrm{C}_{6} \mathrm{H}_{4} \mathrm{OH}$, also led to a linear dependence on [3] with a slope of $4.0 \times 10^{-6} \mathrm{~s}^{-1}$ (Figures S6 and S7). The analogous procedure was employed to determine the rate dependence on [ketone]. In both cases $\left(\mathrm{X}=\mathrm{OMe}, \mathrm{CF}_{3}\right)$, the first-order rate dependence on [4-methoxyacetophenone] was observed under the catalytically relevant ketone concentrations $(0.3-2.0 \mathrm{M})$ (Figure S8 and S9).

In sharp contrast, we observed disparate $\left[\mathrm{H}_{2}\right]$ dependence for the hydrogenolysis reaction between two different phenol ligands, $3 / \mathrm{HBF}_{4} \cdot \mathrm{OEt}_{2} / p-\mathrm{X}-\mathrm{C}_{6} \mathrm{H}_{4} \mathrm{OH}\left(\mathrm{X}=\mathrm{OMe}, \mathrm{CF}_{3}\right)$. Thus, for the hydrogenolysis of 4-methoxyacetophenone catalyzed by $3 / \mathrm{HBF}_{4} \cdot \mathrm{OEt}_{2} / p-\mathrm{OMe}-\mathrm{C}_{6} \mathrm{H}_{4} \mathrm{OH}$, an inverse dependence on $\left[\mathrm{H}_{2}\right]$ was observed within the range of catalytically operating hydrogen pressure (1-4 atm) as indicated by a linear plot of 1 /initial rate $\left(\mathrm{v}_{0}\right)$ vs $\mathrm{H}_{2}$ pressure (Figure 3 ). On the other hand, the plot of the initial rate $\left(\mathrm{v}_{0}\right) \mathrm{vs} \mathrm{H}_{2}$ pressure for the hydrogenolysis of 4-methoxyacetophenone catalyzed by $3 / \mathrm{HBF}_{4} \cdot \mathrm{OEt}_{2} / p-\mathrm{CF}_{3}-\mathrm{C}_{6} \mathrm{H}_{4} \mathrm{OH}$ showed rate independence on $\left[\mathrm{H}_{2}\right]$ in the same range of $\mathrm{H}_{2}$ pressure (1-4 atm). 

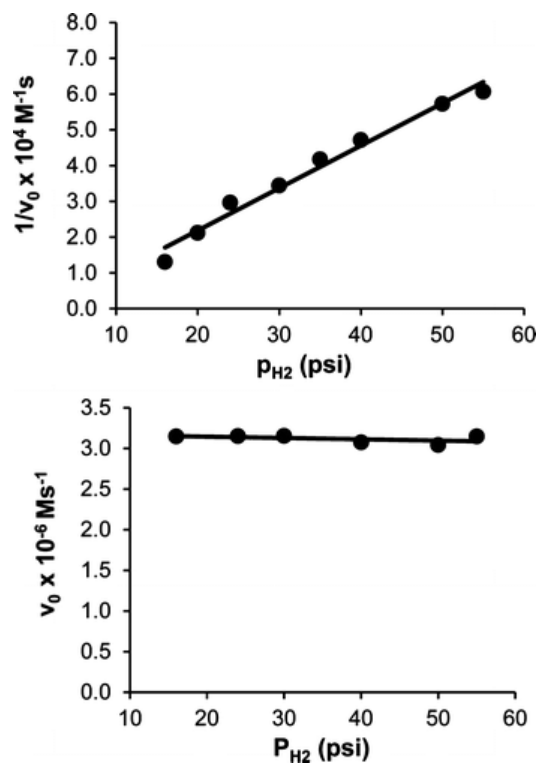

Figure 3. Inverse of the initial rate $\left(\mathrm{v}_{0}\right)$ vs $\mathrm{H}_{2}$ pressure for the hydrogenolysis of 4methoxyacetophenone catalyzed by $3 / \mathrm{HBF}_{4} \cdot \mathrm{OEt} 2 / p-\mathrm{OMe}-\mathrm{C}_{6} \mathrm{H}_{4} \mathrm{OH}$ (top) and initial rate $\left(v_{0}\right)$ vs $\mathrm{H}_{2}$ pressure catalyzed by $3 / \mathrm{HBF}_{4} \cdot \mathrm{OEt}_{2} / p-\mathrm{CF}_{3}-\mathrm{C}_{6} \mathrm{H}_{4} \mathrm{OH}$ (bottom).

On the basis of these kinetic data, two separate empirical rate laws have been compiled for the hydrogenolysis of a ketone:

$$
\text { rate }=k_{\text {obssi }}[\mathrm{Ru}][\text { ketone }]\left[\mathrm{H}_{2}\right]^{-1}
$$

for the hydrogenolysis reaction catalyzed by $1 / p-\mathrm{OMe}-\mathrm{C}_{6} \mathrm{H}_{4} \mathrm{OH}$ and

$$
\text { rate }=k_{\text {obsid }}[\mathrm{Ru}][\text { ketone }]\left[\mathrm{H}_{2}\right]^{0}
$$

for the hydrogenolysis reaction catalyzed by $1 / p-\mathrm{CF}_{3}-\mathrm{C}_{6} \mathrm{H}_{4} \mathrm{OH}$. The inverse rate dependence on $\left[\mathrm{H}_{2}\right]$ for the catalyst $1 / p-\mathrm{OMe}-\mathrm{C}_{6} \mathrm{H}_{4} \mathrm{OH}$ signifies that the hydrogenolysis reaction is inhibited by $\mathrm{H}_{2}$ at a relatively high $\left[\mathrm{H}_{2}\right]$. In this case, the $\mathrm{Ru}$ catalyst with an electronreleasing phenol group is expected to exhibit a relatively strong affinity toward $\mathrm{H}_{2}$, which leads to competitive inhibition with the coordination of the ketone substrate. On the other hand, the rate independence on $\left[\mathrm{H}_{2}\right]$ for the hydrogenolysis by $\mathbf{1} / p-\mathrm{CF}_{3}-\mathrm{C}_{6} \mathrm{H}_{4} \mathrm{OH}$ with an electronwithdrawing phenol ligand indicates that an electron-deficient $\mathrm{Ru}$ catalyst facilitates reversible coordination of $\mathrm{H}_{2}$ but with much lower binding affinity compared to the ketone substrate. 


\section{Isolation and Characterization of Catalytically Relevant Ruthenium Complexes}

We performed a series of reactivity studies on complex $\mathbf{1}$ to detect or isolate catalytically relevant intermediate species (Scheme 5). In an NMR tube reaction, the treatment of 1 with phenol in $\mathrm{CD}_{2} \mathrm{Cl}_{2}$ was followed by ${ }^{1} \mathrm{H}$ and ${ }^{31} \mathrm{P}\left\{{ }^{1} \mathrm{H}\right\}$ NMR. After $1 \mathrm{~h}$ of heating at $80{ }^{\circ} \mathrm{C}$, the formation of a 1:1 ratio of cationic Ru-H complex 1 and the phenol-coordinated complex 4 was observed, as evidenced by the appearance of a new set of peaks $\left({ }^{1} \mathrm{H}\right.$ NMR, $\delta-10.87\left(\mathrm{~d}, J_{\mathrm{PH}}=27.1\right.$ $\left.\mathrm{Hz}) ;{ }^{31} \mathrm{P}\left\{{ }^{1} \mathrm{H}\right\} \mathrm{NMR}, \delta 70.8 \mathrm{ppm}\right)$. The formation of a free benzene molecule was also detected by ${ }^{1} \mathrm{H}$ NMR, but no evidence for $\mathrm{PCy}_{3}$ dissociation was detected under these conditions. In a preparatory scale reaction, para-substituted phenol-coordinated $\mathrm{Ru}-\mathrm{H}$ complexes 4a-4c were conveniently synthesized from the treatment of the tetranuclear Ru complex $\mathbf{3}$ with the corresponding phenol and $\mathrm{HBF}_{4} \cdot \mathrm{OEt}_{2}$, following a similar procedure used to synthesize complex $\mathbf{1}$. The structure of these phenol-coordinated complexes $\mathbf{4 a - 4 c}$ was completely established by X-ray crystallography (Figure 4; Figures S13 and S14). To facilitate trapping of catalytically relevant species, 2acetylphenol-coorinated complex $4 \mathbf{d}$ was prepared from the analogous treatment of 3 with 2-acetylphenol and $\mathrm{HBF}_{4} \cdot \mathrm{Et}_{2} \mathrm{O}$, and it was isolated in $82 \%$ yield after recrystallization in $\mathrm{CH}_{2} \mathrm{Cl}_{2} / n$-pentane. The treatment of 1 with the phenol substrates also formed the complexes $\mathbf{4 a - 4 d}$, but in this case, some unreacted $\mathbf{1}$ and unidentified side products were also presented in the crude mixture.

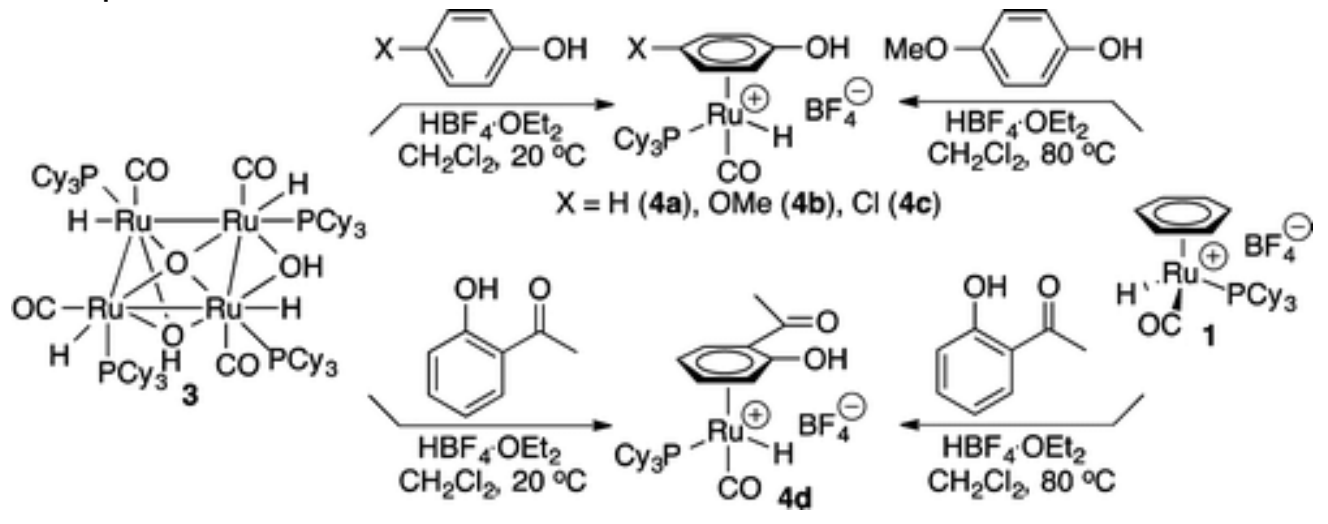

Scheme 5 


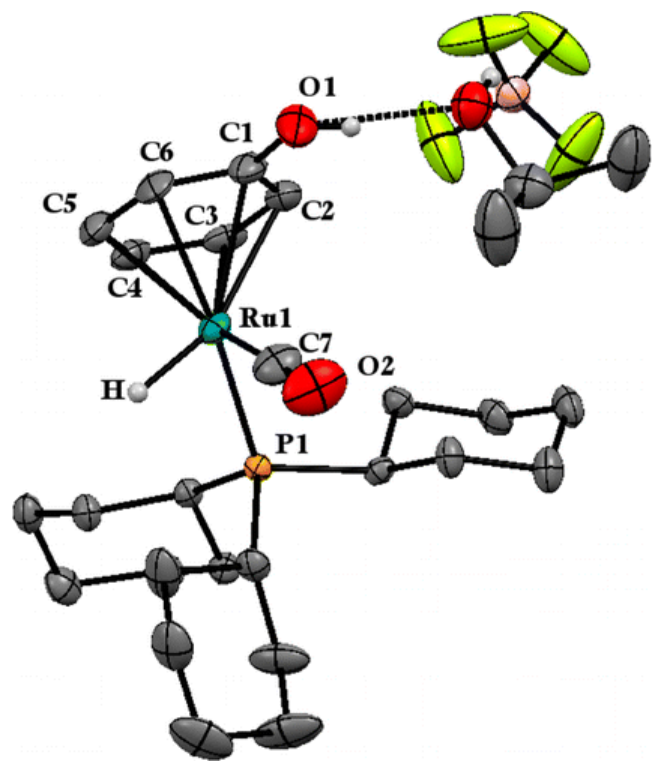

Figure 4. Molecular structure of $\left[\left(\mathrm{C}_{6} \mathrm{H}_{5} \mathrm{OH}\right)\left(\mathrm{PCy}_{3}\right)(\mathrm{CO}) \mathrm{RuH}^{+} \mathrm{BF}_{4}^{-}(\mathbf{4 a})\right.$ cocrystallized with a 2-propanol molecule.

We explored the reactivity of phenol-coordinated complexes 4 to detect or trap catalytically active species. Despite concerted efforts using various external trapping agents and VT NMR techniques, we failed to detect any intermediate species by using complex $\mathbf{4 a}$ with both electron-rich and electron-poor phenol ligands. Recognizing that a carbonyl group might serve as an internal chelate group, we next explored the reactivity of the 2-acetylphenol-coordinated complex 4d, which contains an acyl chelate group. Thus, heating of $\mathbf{4 d}$ in dioxane solution at $80^{\circ} \mathrm{C}$ for $1 \mathrm{~h}$ led to the clean formation of a dinuclear $\mathrm{Ru}-\mathrm{H}$ complex, 5, in this case (Scheme 6). A characteristically upfieldshifted bridging metal hydride resonance appeared at $\delta-28.30\left(t, J_{\mathrm{PH}}\right.$ $=9.5 \mathrm{~Hz})$ in ${ }^{1} \mathrm{H}$ NMR. The observation of a single phosphine peak at $\delta$ $70.7 \mathrm{ppm}$ in ${ }^{31} \mathrm{P}\left\{{ }^{1} \mathrm{H}\right\}$ NMR is also consistent with a symmetric nature of the complex. The X-ray crystal structure confirmed the dinuclear Ru complex of 5, which is joined by two bridging 2-acetylphenolate ligands, with a crystallographic 2-fold symmetry on the Ru core. 


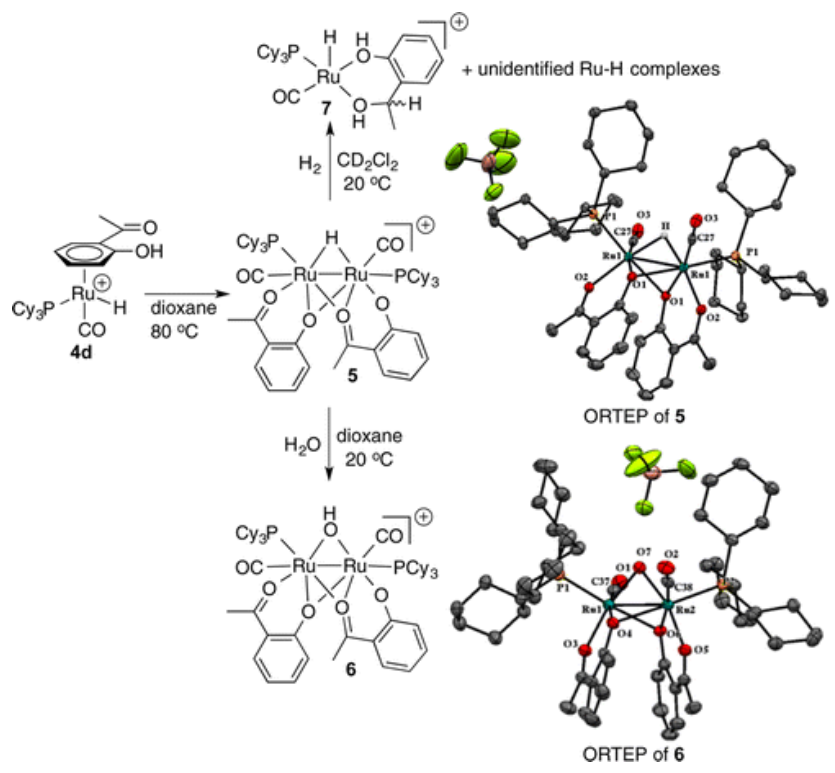

\section{Scheme 6}

The subsequent treatment of the dinuclear $\mathrm{Ru}-\mathrm{H}$ complex $\mathbf{5}$ in wet 1,4-dioxane solution at room temperature smoothly formed the dinclear Ru-hydroxo complex $\mathbf{6}$. The characteristic $\mathrm{Ru}-\mathrm{OH}$ signal at $\delta$ -3.18 was observed by ${ }^{1} \mathrm{H}$ NMR, and the structure of complex 6 was unambiguously determined by X-ray crystallography. Complex $\mathbf{6}$ is molecularly isostructural with complex $\mathbf{5}$, in that each Ru center still retains a pseudooctahedral coordination geometry with two bridging acetophenolate ligands. A considerably longer Ru-Ru distance of 2.948 $\AA$ of 6 compared to the hydride complex $5(2.680 \AA)$ is probably due to the larger ionic radius of the bridging oxygen compared to the hydrogen atom. Both complexes exhibited identical catalytic activity toward the hydrogenolysis of 4-methoxyacetophenone under the conditions specified in eq 1.

The reaction of $5\left(0.02 \mathrm{mmol}\right.$ ) with $\mathrm{H}_{2}$ (2 atm) in $\mathrm{CD}_{2} \mathrm{Cl}_{2}$ was monitored by NMR. At $20{ }^{\circ} \mathrm{C}$, two sets of new peaks appeared $\left({ }^{1} \mathrm{H}\right.$ $\mathrm{NMR}, \delta-19.10\left(\mathrm{~d}, J_{\mathrm{PH}}=16.5 \mathrm{~Hz}\right)$ and $-19.20\left(\mathrm{~d}, J_{\mathrm{PH}}=16.3 \mathrm{~Hz}\right)$; ${ }^{31} \mathrm{P}\left\{{ }^{1} \mathrm{H}\right\} \mathrm{NMR}, \delta 73.45$ and $73.49 \mathrm{ppm}$ ) that have characteristic features for a diastereomeric mixture of $\mathrm{Ru}-\mathrm{H}$ complexes. In light of the recently isolated alcohol-coordinated $\mathrm{Ru}-\mathrm{H}$ complexes, ${ }^{19 \mathrm{~b}}$ we tentatively assign the new set of peaks as the alcohol-coordinated [(2$\left.\mathrm{MeCH}(\mathrm{OH}) \mathrm{C}_{6} \mathrm{H}_{4} \mathrm{OH}\right)\left(\mathrm{PCy}_{3}\right)(\mathrm{CO}) \mathrm{RuH}^{+} \mathrm{BF}_{4}^{-}(7)$. Upon warming to $50{ }^{\circ} \mathrm{C}$, complex $\mathbf{7}$ rapidly decomposed into the aliphatic product $\mathbf{2 a}$ and a 
number of unidentified $\mathrm{Ru}-\mathrm{H}$ complexes. The formation of the alcoholcoordinated complex $\mathbf{7}$ implicates the involvement of a monomeric $\mathrm{Ru}-\eta^{2}-\mathrm{H}_{2}$ complex.

\section{Proposed Mechanism}

Table 5 presents a summary of the kinetic data obtained from the catalytic hydrogenolysis of ketones. On the basis of these kinetic data as well as structural elucidation of the catalytically relevant species, we compile a plausible mechanism for the hydrogenolysis of ketones (Scheme 7). We propose that the ketone hydrogenolysis occurs in two stages: the first stage involves the hydrogenation of the ketone to an alcohol and the second stage the hydrogenolysis of the alcohol to the corresponding aliphatic product. It has been well established that both Shvo- and Noyori-type bifunctional ruthenium catalysts are highly efficient for the hydrogenation of carbonyl compounds to alcohols. ${ }^{32,33}$ Extensive experimental and computational studies have led to the elucidation of a concerted outer-sphere hydrogen transfer mechanism for the catalytic hydrogenation of ketones to alcohols. In our case, the phenol-coordinated cationic ruthenium hydride complex 4 should effectively serve as the catalyst precursor for the hydrogenation of the ketone to give the alcohol product. The observed H/D exchange pattern of the ketone substrate supports that the initial hydrogenation of the ketone to an alcohol is relatively fast under the reaction conditions.

Table 5. Kinetic Parameters Obtained from the Hydrogenolysis of an ArylSubstituted Ketone Catalyzed by $3 / \mathrm{HBF}_{4} \cdot \mathrm{OEt}_{2} / p-\mathrm{X}-\mathrm{C}_{6} \mathrm{H}_{4} \mathrm{OH}\left(\mathrm{X}=\mathrm{OMe}_{2} \mathrm{CF}_{3}\right)$

kinetic parameter

Hammett $\rho^{\mathrm{a}, \mathrm{b}}$

$k_{\mathrm{H}} / k_{\mathrm{D}}^{\mathrm{a}}$

rate law of $\left[\mathrm{H}_{2}\right]^{\mathrm{a}}$

$k_{12 c} / k_{13 c^{c}}$

\section{p-OMe- $\mathrm{C}_{6} \mathrm{H}_{4} \mathrm{OH}$} $-3.3$

2.7

$\left[\mathrm{H}_{2}\right]^{-1}$

1.042
$p-\mathrm{CF}_{3}-\mathrm{C}_{6} \mathrm{H}_{4} \mathrm{OH}$

$+1.5$

0.6

$\left[\mathrm{H}_{2}\right]^{0}$

1.063

aThe data were obtained from the hydrogenolysis reaction of 4-methoxyacetophenone. bThe values represent the correlation of a series of para-substituted phenol ligands as shown in Figure 1.

'The data were obtained from the hydrogenolysis reaction of 6-methoxy-1-tetralone. 


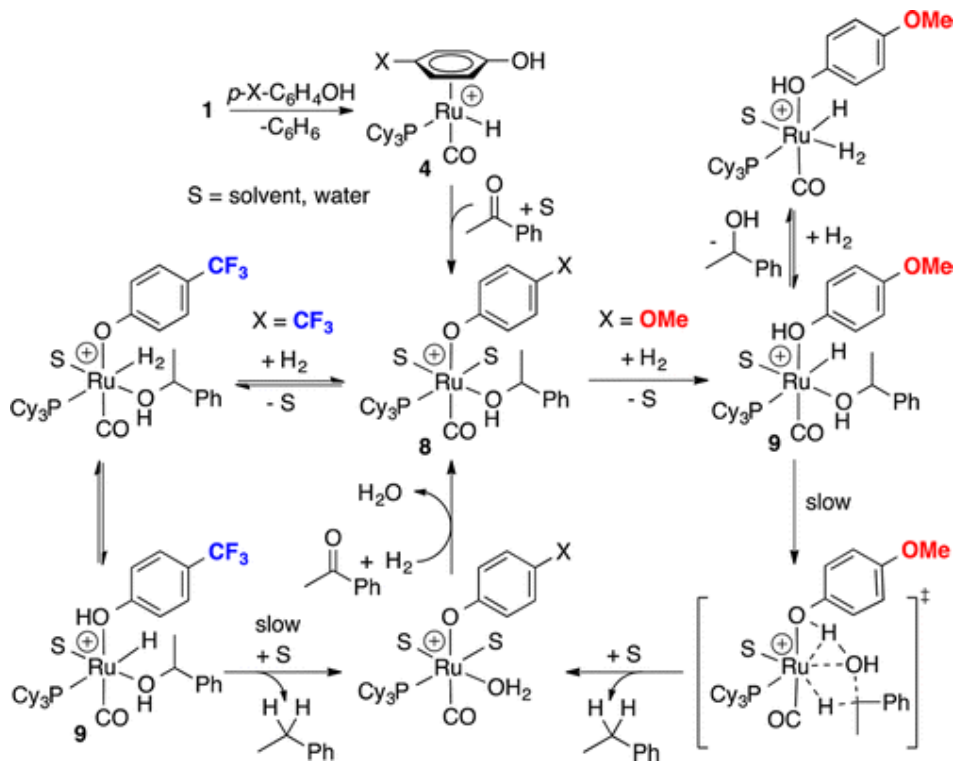

Scheme 7. Proposed Mechanism of the Catalytic Hydrogenolysis of Acetophenone

Compared to the hydrogenation of ketones to alcohols, the mechanism of hydrogenolysis of alcohols to the corresponding aliphatic products has been less well established. Both isotope effect and Hammett data indicate two different mechanistic pathways for the $\mathrm{C}-\mathrm{O}$ bond hydrogenolysis reaction, depending on the electronic nature of the Ru catalyst. In the case of the Ru catalyst with an electronreleasing phenol ligand, $\mathbf{1} / p-\mathrm{OMe}-\mathrm{C}_{6} \mathrm{H}_{4} \mathrm{OH}$, both a normal deuterium isotope effect and inverse $\left[\mathrm{H}_{2}\right]$ dependence are consistent with a mechanistic pathway involving concerted addition of $\mathrm{H}_{2}$. In this case, a relatively electron-rich $\mathrm{Ru}$ center promotes high affinity toward $\mathrm{H}_{2}$, which results in a competitive inhibition with the ketone (and alcohol) substrate at relatively high $\left[\mathrm{H}_{2}\right]$. In light of extensive experimental and computational studies on organo-transition-metal dihydrogen complexes, ${ }^{23,34}$ we propose that the formation of a Ru-dihydrogen complex has led to the inhibition of ketone (and alcohol) substrates. ${ }^{27}$

For the Ru catalyst with an electron-poor phenol ligand, $1 / p$ $\mathrm{CF}_{3}-\mathrm{C}_{6} \mathrm{H}_{4} \mathrm{OH}$, an electron-deficient $\mathrm{Ru}$ center would have a relatively low $\mathrm{H}_{2}$ binding affinity. In this case, the observed inverse deuterium isotope effect is consistent with a stepwise reversible binding and activation of $\mathrm{H}_{2}$ by an electrophilic Ru catalyst. The rate independence on $\left[\mathrm{H}_{2}\right]$ supports this notion in that the coordination of the ketone or alcohol substrate would be favored over the $\mathrm{H}_{2}$ binding. In transitionmetal-mediated $\mathrm{H}-\mathrm{H}$ and $\mathrm{C}-\mathrm{H}$ activation reactions, an inverse 
deuterium isotope effect has been commonly interpreted as having a stepwise equilibrium partitioning of coordinated substrates. ${ }^{24}$ In our case, we reason that a stepwise reversible binding and activation of $\mathrm{H}_{2}$ via bifunctional Ru-phenoxo species $\mathbf{8}$ would be most consistent with the observed kinetics, but we still cannot fully explain why the rate is independent of $\left[\mathrm{H}_{2}\right]$ even though an inverse $\mathrm{KIE}$ has been measured from the hydrogenolysis reaction. ${ }^{35}$ As indicated by the carbon isotope effect on the carbonyl carbon of the product, the $\mathrm{C}-\mathrm{O}$ bond cleavage step is the turnover-limiting step of the hydrogenolysis reaction for both electron-releasing and -withdrawing phenol ligands $1 / p-\mathrm{X}-\mathrm{C}_{6} \mathrm{H}_{4} \mathrm{OH}$ $\left(\mathrm{X}=\mathrm{OMe}, \mathrm{CF}_{3}\right)$.

The successful isolation of the bimetallic Ru-acetylphenoxo complexes $\mathbf{5}$ and $\mathbf{6}$ provides strong support for the cationic Ruphenoxo complex $\mathbf{8}$ as the catalytically active species for the hydrogenolysis reaction. To avoid the generation of a relatively high energy $\mathrm{Ru}(\mathrm{IV})$ species, we propose that the $\mathrm{H}-\mathrm{H}$ activation is facilitated by the bifunctional Ru-phenoxo species $\mathbf{8}$, in which an electrophilic Ru center and nucleophilic phenoxy group would promote the heterolytic cleavage of a $\mathrm{H}-\mathrm{H}$ bond in forming the $\mathrm{Ru}-\mathrm{H}$ species 9. The detection of structurally similar cationic $\mathrm{Ru}-\mathrm{H}$ complex $\mathbf{7}$ also shed light on the involvement of a cationic Ru-H species such as 9. Many Ru-alkoxo and -phenoxo complexes have been synthesized, as these complexes are considered to be key species for the hydrogenation of ketones to alcohols. ${ }^{36}$ In a notable example, Gunnoe and Cundari showed that the $\sigma$-bond metathesis path is favored over the classical $\mathrm{Ru}(\mathrm{II}) / \mathrm{Ru}(\mathrm{IV})$ oxidative addition-reductive elimination pathway for $\mathrm{Ru}$ (II)-catalyzed $\mathrm{C}-\mathrm{H}$ arylation reactions on the basis of both experimental and computational studies. ${ }^{37}$ The computational study on our cationic Ru(II) catalytic system is certainly warranted in establishing the detailed energetics and mechanism of the $\mathrm{C}-\mathrm{O}$ bond hydrogenolysis step.

\section{Conclusions}

We successfully developed a highly effective catalytic hydrogenolysis method for carbonyl compounds and alcohols by using a well-defined cationic Ru-H complex with a tunable phenol ligand. The salient features of the catalytic method are that it employs 
cheaply available $\mathrm{H}_{2}$, it exhibits high chemoselectivity toward the carbonyl reduction over olefin hydrogenation without forming any wasteful byproducts, and its activity can be readily modulated by employing phenol ligands. The detailed kinetic and mechanistic analyses revealed two distinct mechanistic pathways that are guided by the electronic nature of the Ru catalyst $1 / p-\mathrm{X}-\mathrm{C}_{6} \mathrm{H}_{4} \mathrm{OH}$. The $\mathrm{Ru}$ catalyst with an electron-releasing phenol ligand, $1 / p-\mathrm{OMe}-\mathrm{C}_{6} \mathrm{H}_{4} \mathrm{OH}$, facilitates the hydrogenolysis through concerted $\mathrm{H}_{2}$ addition, while the electron-deficient Ru catalyst $\mathbf{1} / p-\mathrm{CF}_{3}-\mathrm{C}_{6} \mathrm{H}_{4} \mathrm{OH}$ features a stepwise binding and activation of $\mathrm{H}_{2}$ and electrophilic hydrogenolysis of the alcohol substrate. The catalytic method provides a chemoselective and cost-effective protocol for the hydrogenolysis of aldehydes and ketones under environmentally sustainable conditions.

\section{Supporting Information}

The Supporting Information is available free of charge on the ACS Publications website at DOI: 10.1021/jacs.5b06097.

- Experimental procedures and methods, kinetic and characterization

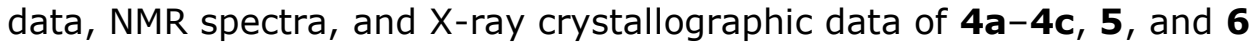
(PDF)

- X-ray crystallographic data of $\mathbf{4 a}$ (CIF)

- X-ray crystallographic data of $\mathbf{4 b}$ (CIF)

- X-ray crystallographic data of $\mathbf{5}$ (CIF)

- X-ray crystallographic data of $\mathbf{6}$ (CIF)

The authors declare no competing financial interest.

\section{Acknowledgment}

Financial support from the National Science Foundation (Grant CHE-1358439) is gratefully acknowledged. We thank Dr. Sergey Lindeman (Marquette University) for X-ray structural determination of $\mathbf{4 a - 4 c}, \mathbf{5}$, and $\mathbf{6}$.

\section{References}

${ }^{1}$ Reviews: (a) Zhou, C.-H.; Beltramini, J. N.; Fan, Y.-X.; Lu, G. Q. Chem. Soc. Rev. 2008, 37, 527, DOI: 10.1039/B707343G (b) Ruppert, A. M.; Weinberg, K.; Palkovits, R. Angew. Chem., Int. Ed. 2012, 51, 2564, DOI: 10.1002/anie.201105125 (c) Alonso, D. M.; Wettstein, S. G.; 
NOT THE PUBLISHED VERSION; this is the author's final, peer-reviewed manuscript. The published version may be

accessed by following the link in the citation at the bottom of the page.

Dumesic, J. A. Chem. Soc. Rev. 2012, 41, 8075, DOI:

$10.1039 / \mathrm{c} 2 \mathrm{cs} 35188 \mathrm{a}$

${ }^{2}$ (a) House, H. O. Modern Synthetic Reactions, 2nd Ed.; Benjamin: Menlo

Park, CA, 1972. (b) Todd, D. Org. React. 1948, 4, 378 (c) Szmant, H.

H. Angew. Chem., Int. Ed. Engl. 1968, 7, 120, DOI:

10.1002/anie.196801201 (d) Vedejs, E. Org. React. 1975, 22, 401

${ }^{3}$ Recent reviews: (a) Gallezot, P. Chem. Soc. Rev. 2012, 41, 1538, DOI:

10.1039/C1CS15147A (b) Nakagawa, Y.; Tamura, M.; Tomishige, K.

ACS Catal. 2013, 3, 2655, DOI: 10.1021/cs400616p

${ }^{4}$ (a) Gunanathan, C.; Milstein, D. Acc. Chem. Res. 2011, 44, 588, DOI:

10.1021/ar2000265 (b) Gunanathan, C.; Milstein, D. Chem. Rev.

2014, 114, 12024, DOI: 10.1021/cr5002782

5(a) vom Stein, T.; Meuresch, M.; Limper, D.; Schmitz, M.; Hölscher, M.;

Coetzee, J.; Cole-Hamilton, D. J.; Klankermayer, J.; Leitner, W. J. Am.

Chem. Soc. 2014, 136, 13217, DOI: 10.1021/ja506023f (b)

Chakraborty, S.; Dai, H.; Bhattacharya, P.; Fairweather, N. T.; Gibson, M. S.; Krause, J. A.; Guan, H. J. Am. Chem. Soc. 2014, 136, 7869, DOI: 10.1021/ja504034q (c) Qu, S.; Dai, H.; Dang, Y.; Song, C.; Wang, Z.-X.; Guan, H. ACS Catal. 2014, 4, 4377, DOI:

$10.1021 / \operatorname{cs} 501089 \mathrm{~h}$

${ }^{6}$ (a) Cheng, C.; Brookhart, M. J. Am. Chem. Soc. 2012, 134, 11304, DOI:

10.1021/ja304547s (b) Brewster, T. P.; Miller, A. J. M.; Heinekey, D.

M.; Goldberg, K. I. J. Am. Chem. Soc. 2013, 135, 16022, DOI:

10.1021/ja408149n (c) Lao, D. B.; Owens, A. C. E.; Heinekey, D. M.; Goldberg, K. I. ACS Catal. 2013, 3, 2391, DOI: 10.1021/cs400551g

(d) McLaughlin, M. P.; Adduci, L. L.; Becker, J. J.; Gagné, M. R. J. Am.

Chem. Soc. 2013, 135, 1225, DOI: 10.1021/ja3110494

${ }^{7}$ (a) Rahaim, R. J., Jr.; Maleczka, R. E., Jr. Org. Lett. 2011, 13, 584, DOI: 10.1021/ol102757v (b) Wang, S.; Yin, K.; Zhang, Y.; Liu, H. ACS Catal. 2013, 3, 2112, DOI: 10.1021/cs400486z (c) Zarate, C.; Martin, R. J. Am. Chem. Soc. 2014, 136, 2236, DOI: 10.1021/ja412107b (d) Volkov, A.; Gustafson, K. P. J.; Tai, C.-W.; Verho, O.; Bäckvall, J.-E.; Adolfsson, H. Angew. Chem., Int. Ed. 2015, 54, 5122, DOI: 10.1002/anie. 201411059

8(a) Corma, A.; de la Torre, O.; Renz, M.; Villandier, N. Angew. Chem., Int. Ed. 2011, 50, 2375, DOI: 10.1002/anie.201007508 (b) Sutton, A. D.; Waldie, F. D.; Wu, R.; Schlaf, M.; Silks, L. A., III; Gordon, J. C. Nat. Chem. 2013, 5, 428, DOI: 10.1038/nchem.1609

${ }^{9}$ (a) Sakai, N.; Moriya, T.; Konakahara, T. J. Org. Chem. 2007, 72, 5920, DOI: 10.1021/jo070814z (b) Sunada, Y.; Kawakami, H.; Imaoka, T.; Motoyama, Y.; Nagashima, H. Angew. Chem., Int. Ed. 2009, 48, 9511, DOI: 10.1002/anie.200905025 (c) Das, S.; Addis, D.; Zhou, S.;

Journal of the American Chemical Society, Vol 137, No. 34 (August 2, 2015): pg. 11105-11114. DOI. This article is (C) American Chemical Society and permission has been granted for this version to appear in e-Publications@Marquette. American Chemical Society does not grant permission for this article to be further copied/distributed or hosted elsewhere without the express permission from American Chemical Society. 
NOT THE PUBLISHED VERSION; this is the author's final, peer-reviewed manuscript. The published version may be accessed by following the link in the citation at the bottom of the page.

Junge, K.; Beller, M. J. Am. Chem. Soc. 2010, 132, 1770, DOI: 10.1021/ja101189c

${ }^{10}$ (a) McCombie, S. W. In Comprehensive Organic Synthesis; Trost, B. M.; Fleming, I., Eds.; Pergamon Press: Oxford, U.K., 1991; Vol. 8, Chapter 4.2. (b) McMurry, J. E. Chem. Rev. 1989, 89, 1513, DOI: 10.1021/cr00097a007

${ }^{11}$ (a) Barton, D. H. R.; McCombie, S. W. J. Chem. Soc., Perkin Trans. 1 1975, 1574, DOI: $10.1039 /$ p19750001574 (b) Zard, S. Z. Angew. Chem., Int. Ed. Engl. 1997, 36, 672, DOI: 10.1002/anie.199706721 (c) Zhang, L.; Koreeda, M. J. Am. Chem. Soc. 2004, 126, 13190, DOI: 10.1021/ja0462777 (d) Spiegel, D. A.; Wiberg, K. B.; Schacherer, L. N.; Medeiros, M. R.; Wood, J. L. J. Am. Chem. Soc. 2005, 127, 12513, DOI: $10.1021 /$ ja052185I (e) Diéguez, H. R.; López, A.; Domingo, V.; Arteaga, J. F.; Dobado, J. A.; Herrador, M. M.; del Moral, J. F. Q.; Barrero, A. F. J. Am. Chem. Soc. 2010, 132, 254, DOI: 10.1021/ja906083c (f) Herrmann, J. M.; König, B. Eur. J. Org. Chem. 2013, 2013, 7017, DOI: 10.1002/ejoc.201300657 (g) Dang, H.; Cox, N.; Lalic, G. Angew. Chem., Int. Ed. 2014, 53, 752, DOI: 10.1002/anie.201307697

${ }^{12}$ (a) Sergeev, A. G.; Hartwig, J. F. Science 2011, 332, 439, DOI: 10.1126/science.1200437 (b) Sergeev, A. G.; Webb, J. D.; Hartwig, J. F. J. Am. Chem. Soc. 2012, 134, 20226, DOI: 10.1021/ja3085912

${ }^{13}$ (a) Son, S.; Toste, F. D. Angew. Chem., Int. Ed. 2010, 49, 3791, DOI: 10.1002/anie.201001293 (b) Nichols, J. M.; Bishop, L. M.; Bergman, R. G.; Ellman, J. A. J. Am. Chem. Soc. 2010, 132, 12554, DOI: 10.1021/ja106101f (c) Atesin, A. C.; Ray, N. A.; Stair, P. C.; Marks, T. J. J. Am. Chem. Soc. 2012, 134, 14682, DOI: 10.1021/ja306309u (d) Chen, C.; Hong, S. H. Org. Lett. 2012, 14, 2992, DOI: 10.1021/ol3009842 (e) Kelley, P.; Lin, S.; Edouard, G.; Day, M. W.; Agapie, T. J. Am. Chem. Soc. 2012, 134, 5480, DOI: 10.1021/ja300326t (f) Hanson, S. K.; Wu, R.; Silks, L. A. Angew. Chem., Int. Ed. 2012, 51, 3410, DOI: 10.1002/anie.201107020 (g) Ren, Y.; Yan, M.; Wang, J.; Zhang, Z. C.; Yao, K. Angew. Chem., Int. Ed. 2013, 52, 12674, DOI: 10.1002/anie.201305342

${ }^{14}$ (a) Gosselink, R. W.; Stellwagen, D. R.; Bitter, J. H. Angew. Chem., Int. Ed. 2013, 52, 5089, DOI: 10.1002/anie.201209809 (b) Sousa, S. C. A.; Fernandes, A. C. Coord. Chem. Rev. 2015, 284, 67, DOI: 10.1016/j.ccr.2014.09.008 (c) Harms, R. G.; Herrmann, W. A.; Kühn, F. E. Coord. Chem. Rev. 2015, 296, 1, DOI: 10.1016/j.ccr.2015.03.015

${ }^{15}$ (a) Yan, N.; Zhao, C.; Luo, C.; Dyson, P. J.; Liu, H.; Kou, Y. J. Am. Chem. Soc. 2006, 128, 8714, DOI: 10.1021/ja062468t (b) Chia, M.; PáganTorres, Y. J.; Hibbitts, D.; Tan, Q.; Pham, H. N.; Datye, A. K.; 
Neurock, M.; Davis, R. J.; Dumesic, J. A. J. Am. Chem. Soc. 2011, 133, 12675, DOI: 10.1021/ja2038358 (c) Chen, K.; Mori, K.; Watanabe, H.; Nakagawa, Y.; Tomishige, K. J. Catal. 2012, 294, 171, DOI: 10.1016/j.jcat.2012.07.015 (d) He, J.; Zhao, C.; Lercher, J. A. J. Am. Chem. Soc. 2012, 134, 20768, DOI: 10.1021/ja309915e (e) Sawadjoon, S.; Lundstedt, A.; Samec, J. S. M. ACS Catal. 2013, 3, 635, DOI: 10.1021/cs300785r (f) Li, Z.; Assary, R. S.; Atesin, A. C.; Curtiss, L. A.; Marks, T. J. J. Am. Chem. Soc. 2014, 136, 104, DOI: 10.1021/ja411546r (g) Molinari, V.; Giordano, C.; Antonietti, M.; Esposito, D. J. Am. Chem. Soc. 2014, 136, 1758, DOI: 10.1021/ja4119412 (h) Zaheer, M.; Kempe, R. ACS Catal. 2015, 5, 1675, DOI: $10.1021 / \operatorname{cs} 501498 f$

${ }^{16}$ (a) Haw, J. F.; Song, W.; Marcus, D. M.; Nicholas, J. B. Acc. Chem. Res. 2003, 36, 317, DOI: 10.1021/ar020006o (b) Wang, S.; Wei, Z.; Chen, Y.; Qin, Z.; Ma, H.; Dong, M.; Fan, W.; Wang, J. ACS Catal. 2015, 5, 1131, DOI: 10.1021/cs501232r (c) Tian, P.; Wei, Y.; Ye, M.; Liu, Z. ACS Catal. 2015, 5, 1922, DOI: 10.1021/acscatal.5b00007

${ }^{17}$ Recent reviews: (a) Corma, A.; Iborra, S.; Velty, A. Chem. Rev. 2007, 107, 2411, DOI: 10.1021/cr050989d (b) Zakzeski, J.; Bruijnincx, P. C. A. ; Jongerius, A. L.; Weckhuysen, B. M. Chem. Rev. 2010, 110, 3552, DOI: $10.1021 /$ cr900354u (c) Climent, M. J.; Corma, A.; Iborra, S. Green Chem. 2014, 16, 516, DOI: 10.1039/c3gc41492b (d) Barta, K.; Ford, P. C. Acc. Chem. Res. 2014, 47, 1503, DOI: 10.1021/ar4002894

${ }^{18}$ (a) Lee, D.-H.; Kwon, K.-H.; Yi, C. S. Science 2011, 333, 1613, DOI: 10.1126/science.1208839 (b) Lee, D.-H.; Kwon, K.-H.; Yi, C. S. J. Am. Chem. Soc. 2012, 134, 7325, DOI: 10.1021/ja302710v

${ }^{19}$ (a) Kim, J.; Lee, D.-H.; Kalutharage, N.; Yi, C. S. ACS Catal. 2014, 4, 3881, DOI: $10.1021 / \operatorname{cs} 5012537$ (b) Kalutharage, N.; Yi, C. S. Org. Lett. 2015, 17, 1778, DOI: 10.1021/acs.orglett.5b00553

${ }^{20}$ (a) Yi, C. S.; Zeczycki, T. N.; Lindeman, S. V. Organometallics 2008, 27, 2030, DOI: 10.1021/om800053q (b) Yi, C. S.; Lee, D. W. Organometallics 2010, 29, 1883, DOI: 10.1021/om100051h

${ }^{21}$ We tried to measure the relative rates using an electron-deficient ketone substrate, 4-(trifluoromethyl)acetophenone. In this case, the rates were much slower than those of 4-methoxyacetophenone for both electron-donating and electron-withdrawing phenol ligands, which prevented us from measuring the inital rates accurately.

${ }^{22}$ (a) Swansburg, S.; Buncel, E.; Lemieux, R. P. J. Am. Chem. Soc. 2000, 122, 6594, DOI: 10.1021/ja0001613 (b) Zdilla, M. J.; Dexheimer, J. L. ; Abu-Omar, M. M. J. Am. Chem. Soc. 2007, 129, 11505, DOI: 10.1021/ja073027s (c) Neu, H. M.; Yang, T.; Baglia, R. A.; Yosca, T. H.; Green, M. T.; Quesne, M. G.; de Visser, S. P.; Goldberg, D. P. J. Am. Chem. Soc. 2014, 136, 13845, DOI: 10.1021/ja507177h 
NOT THE PUBLISHED VERSION; this is the author's final, peer-reviewed manuscript. The published version may be accessed by following the link in the citation at the bottom of the page.

${ }^{23}$ (a) Jessop, P. G.; Morris, R. H. Coord. Chem. Rev. 1992, 121, 155, DOI: 10.1016/0010-8545(92)80067-2 (b) Kubas, G. J. J. Organomet. Chem. 2001, 635, 37, DOI: 10.1016/S0022-328X(01)01066-X (c) Clapham, S. E.; Hadzovic, A.; Morris, R. H. Coord. Chem. Rev. 2004, 248, 2201, DOI: $10.1016 /$ j.ccr.2004.04.007

${ }^{24}$ (a) Jones, W. D. Acc. Chem. Res. 2003, 36, 140, DOI: 10.1021/ar020148i

(b) Gómez-Gallego, M.; Sierra, M. A. Chem. Rev. 2011, 111, 4857, DOI: $10.1021 / \mathrm{cr} 100436 \mathrm{k}$

${ }^{25}$ (a) Rabinovich, D.; Parkin, G. J. Am. Chem. Soc. 1993, 115, 353, DOI: 10.1021/ja00054a055 (b) Yi, C. S.; Lee, D. W. Organometallics 1999, 18, 5152, DOI: 10.1021/om990493k (c) Yi, C. S.; He, Z.; Guzei, I. A. Organometallics 2001, 20, 3641, DOI: 10.1021/om010560m (d) Janak, K. E.; Parkin, G. J. Am. Chem. Soc. 2003, 125, 13219, DOI: $10.1021 / \mathrm{ja0} 362611$

${ }^{26}$ (a) Singleton, D. A.; Thomas, A. A. J. Am. Chem. Soc. 1995, 117, 9357, DOI: $10.1021 / j a 00141 a 030$ (b) Frantz, D. E.; Singleton, D. A.; Snyder, J. P. J. Am. Chem. Soc. 1997, 119, 3383, DOI: 10.1021/ja9636348 (c) Nowlan, D. T., III; Gregg, T. M.; Davies, H. M. L.; Singleton, D. A. J. Am. Chem. Soc. 2003, 125, 15902, DOI: 10.1021/ja036025q

${ }^{27} \mathrm{As}$ expressed in the overall rate law and deuterium isotope effect, both $\mathrm{H}-\mathrm{H}$ and $\mathrm{C}-\mathrm{O}$ cleavage steps could be irreversible for the hydrogenolysis reaction catalyzed by $\mathrm{Ru}$ catalyst with an electron-rich phenol ligand. As a reviewer pointed out, an irreversible and partially rate determining $\mathrm{H}-\mathrm{H}$ activation step would still be consistent with the observed kinetic data in this case.

${ }^{28}$ (a) Frantz, D. E.; Singleton, D. A. J. Am. Chem. Soc. 2000, 122, 3288, DOI: 10.1021/ja993373c (b) Singleton, D. A.; Wang, Z. J. Am. Chem. Soc. 2005, 127, 6679, DOI: 10.1021/ja0435788

${ }^{29}$ Recent reviews: (a) Yu, D.-G.; Li, B.-J.; Shi, Z.-J. Acc. Chem. Res. 2010, 43, 1486, DOI: 10.1021/ar100082d (b) Cornella, J.; Zarate, C.; Martin, R. Chem. Soc. Rev. 2014, 43, 8081, DOI: 10.1039/C4CS00206G (c) Tobisu, M.; Chatani, N. Acc. Chem. Res. 2015, 48, 1717, DOI: 10.1021/acs.accounts.5b00051

${ }^{30}$ (a) Kakiuchi, F.; Murai, S. Acc. Chem. Res. 2002, 35, 826, DOI: 10.1021/ar960318p (b) Kakiuchi, F.; Kochi, T.; Mizushima, E.; Murai, S. J. Am. Chem. Soc. 2010, 132, 17741, DOI: 10.1021/ja104918f (c) Albrecht, M. Chem. Rev. 2010, 110, 576, DOI: 10.1021/cr900279a

${ }^{31}$ (a) Yung, C. M.; Skaddan, M. B.; Bergman, R. G. J. Am. Chem. Soc. 2004, 126, 13033, DOI: 10.1021/ja046825g (b) Atzrodt, J.; Derdau, V.; Fey, T.; Zimmermann, J. Angew. Chem., Int. Ed. 2007, 46, 7744, DOI: 10.1002/anie.200700039 (c) Carrión, M. C.; Ruiz-Castañeda, M.; Espino, G.; Aliende, C.; Santos, L.; Rodríguez, A. M.; Manzano, B. 
NOT THE PUBLISHED VERSION; this is the author's final, peer-reviewed manuscript. The published version may be

accessed by following the link in the citation at the bottom of the page.

R.; Jalón, F. A.; Lledós, A. ACS Catal. 2014, 4, 1040, DOI: $10.1021 / \mathrm{cs} 401224 \mathrm{~g}$

${ }^{32}$ (a) Conley, B. L.; Pennington-Boggio, M. K.; Boz, E.; Williams, T. J. Chem. Rev. 2010, 110, 2294, DOI: 10.1021/cr9003133 (b) Warner, M. C.; Bäckvall, J.-E. Acc. Chem. Res. 2013, 46, 2545, DOI: 10.1021/ar400038g (c) Wang, D.; Astruc, D. Chem. Rev. 2015, 115, 6621, DOI: 10.1021/acs.chemrev.5b00203

${ }^{33}$ (a) Noyori, R.; Hashiguchi, S. Acc. Chem. Res. 1997, 30, 97, DOI: 10.1021/ar9502341 (b) Noyori, R.; Ohkuma, T. Angew. Chem., Int. Ed. 2001, 40, 40, DOI: 10.1002/1521-3773(20010105)40:1<40::AIDANIE40>3.0.CO;2-5

${ }^{34}$ (a) Heinekey, D. M.; Oldham, W. J. Chem. Rev. 1993, 93, 913, DOI: 10.1021/cr00019a004 (b) Niu, S.; Hall, M. B. Chem. Rev. 2000, 100, 353, DOI: 10.1021/cr980404y (c) Alcaraz, G.; Grellier, M.; SaboEtienne, S. Acc. Chem. Res. 2009, 42, 1640, DOI: 10.1021/ar900091a

${ }^{35} \mathrm{~A}$ reviewer raised an issue about an apparent inconsistency between inverse $\mathrm{KIE}$ and $\left[\mathrm{H}_{2}\right]$ independence for the hydrogenolysis reaction catalyzed by Ru catalyst with an electron-poor phenol ligand. One possible explanation for the $\left[\mathrm{H}_{2}\right]$ independence is that the $\mathrm{H}_{2}$ activation step is much faster than the $\mathrm{C}-\mathrm{O}$ cleavage step but with a low binding affinity under "saturated" catalytic conditions. Another possibility is that the $\mathrm{C}-\mathrm{O}$ cleavage occurs prior to the $\mathrm{H}_{2}$ activation step. We cannot distinguish between these possible scenarios on the basis of currently available kinetic data. In a relevant study, Berke and co-workers recently reported a detailed mechanistic study on the olefin hydrogenation reaction catalyzed by a Re-nitrosyl complex, in which an inverse KIE and fast H/D scrambling data have been explained by heterolytic $\mathrm{H}-\mathrm{H}$ cleavage via a bifunctional $\mathrm{Re}$-bent nitrosyl species. Jiang, Y.; Schirmer, B.; Blacque, O.; Fox, T.; Grimme, S.; Berke, H. J. Am. Chem. Soc. 2013, 135, 4088, DOI: 10.1021/ja400135d

${ }^{36}$ (a) Bryndza, H. E.; Tam, W. Chem. Rev. 1988, 88, 1163, DOI: 10.1021/cr00089a009 (b) Arnold, P. L.; Scarisbrick, A. C. Organometallics 2004, 23, 2519, DOI: 10.1021/om0498091 (c) Baratta, W.; Chelucci, G.; Gladiali, S.; Siega, K.; Toniutti, M.; Zanette, M.; Zangrando, E.; Rigo, P. Angew. Chem., Int. Ed. 2005, 44, 6214, DOI: 10.1002/anie.200502118 (d) Hamilton, R. J.; Bergens, S. H. J. Am. Chem. Soc. 2008, 130, 11979, DOI: 10.1021/ja8034812 (e) Takebayashi, S.; Dabral, N.; Miskolzie, M.; Bergens, S. H. J. Am. Chem. Soc. 2011, 133, 9666, DOI: 10.1021/ja202732q

${ }^{37}$ (a) Foley, N. A.; Lee, J. P.; Ke, Z.; Gunnoe, T. B.; Cundari, T. R. Acc. Chem. Res. 2009, 42, 585, DOI: 10.1021/ar800183j (b) Joslin, E. E.; McMullin, C. L.; Gunnoe, T. B.; Cundari, T. R.; Sabat, M.; Myers, W. H. Organometallics 2012, 31, 6851, DOI: 10.1021/om300676e 